\title{
WUSCHEL acts as a rheostat on the auxin pathway to maintain apical stem cells in Arabidopsis
}

\author{
Yanfei Ma1§, Andrej Miotk'ş, Zoran Šutiković1§̧, Anna Medzihradszky', \\ Christian Wenzl'1, Olga Ermakova1, Christophe Gaillochet ${ }^{1}$, Joachim

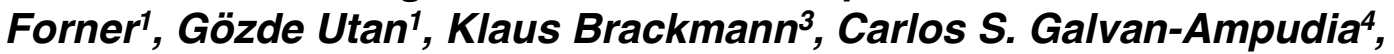 \\ Teva Vernoux ${ }^{4}$, Thomas Greb² \& Jan U. Lohmann ${ }^{1 *}$
}

1Department of Stem Cell Biology, Centre for Organismal Studies, Heidelberg University; D-69120 Heidelberg, Germany

2Department of Developmental Physiology, Centre for Organismal Studies, Heidelberg University; D-69120 Heidelberg, Germany

${ }^{3}$ Gregor Mendel Institute (GMI), Austrian Academy of Sciences, Vienna Biocenter (VBC), Dr. Bohr-Gasse 3, 1030 Vienna, Austria

${ }^{4}$ Laboratoire Reproduction et Développement des Plantes, Univ Lyon, ENS de Lyon, UCB Lyon 1, CNRS, INRA, F-69342 Lyon, France

$\S$ these authors contributed equally and are listed alphabetically

${ }^{*}$ corresponding author

Mailing address of corresponding author:

Jan U. Lohmann

Department of Stem Cell Biology

University of Heidelberg

Im Neuenheimer Feld $230 \quad$ PH: +496221 546269

D-69120 Heidelberg

FX: +496221546424

Germany

EM: jlohmann@meristemania.org 


\section{ABSTRACT}

To maintain the balance between long-term stem cell self-renewal and differentiation, dynamic signals need to be translated into spatially precise and temporally stable gene expression states. In the apical plant stem cell system, local accumulation of the small, highly mobile phytohormone auxin triggers differentiation while at the same time, pluripotent stem cells are maintained throughout the entire life-cycle. We find that stem cells are resistant to auxin mediated differentiation, but require low levels of signaling for their maintenance. We demonstrate that the WUSCHEL transcription factor confers this behavior by rheostatically controlling the auxin signaling and response pathway. Finally, we show that WUSCHEL acts via regulation of histone acetylation at target loci, including those with functions in the auxin pathway. Our results reveal an important mechanism that allows cells to differentially translate a potent and highly dynamic developmental signal into stable cell behavior with high spatial precision and temporal robustness. 


\section{INTRODUCTION}

The shoot apical meristem (SAM) is a highly dynamic and continuously active stem cell system responsible for the generation of all above ground tissues of plants. The stem cells are located in the central zone and are maintained by a feedback loop consisting of the stem cell promoting WUSCHEL (WUS) homeodomain transcription factor and the restrictive CLAVATA (CLV) pathway ${ }^{1,2}$. WUS protein is produced by a group of niche cells, called organizing center, localized in the deeper tissue layers of the meristem ${ }^{3}$ and moves to stem cells via plasmodesmata ${ }^{4,5}$. WUS is required for maintaining stem cells and SAMs of wus mutants terminate due to stem cell exhaustion after producing a small number of organs ${ }^{6}$. Conversely, mutants in genes of the CLV pathway exhibit substantial stem cell over-proliferation, which is strictly dependent on WUS activity ${ }^{1,2}$. CLV3 is the only component of this system that is specifically expressed in stem cells and hence serves as a faithful molecular marker. Stem cells are surrounded by transient amplifying cells, which are competent to undergo differentiation in response to auxin, a small, mobile signaling molecule with diverse and context specific roles in plant development and physiology (reviewed in ref. 7). Auxin sensing is dependent on nuclear receptors including TRANSPORT INHIBITOR RESPONSE1 (TIR1), whose activation triggers the proteolytic degradation of AUX/IAA proteins, such as BODENLOS (BDL). AUX/IAA proteins repress auxin responses by inhibiting the function of activating AUXIN RESPONSE FACTOR (ARF) transcription factors via dimerization ${ }^{8-10}$. Intracellular accumulation of auxin is regulated by active polar transport and in the context of the SAM, the export carrier PINFORMED1 (PIN1) determines the sites of lateral organ initiation and thus differentiation ${ }^{11,12}$. In addition to promoting organ initiation, auxin influences stem cell proliferation by interacting with the signaling cascade of another classical phytohormone, cytokinin, and allows lateral organs to communicate with the center of the meristem ${ }^{13-15}$. Here we ask how longterm stem cell fate is robustly maintained within a tissue environment that is subject to such a highly dynamic signaling system geared towards differentiation. 


\section{RESULTS}

\section{Role of auxin signaling for apical stem cell fate}

To analyze auxin distribution and response with cellular resolution across the homeostatic apical stem cell system of Arabidopsis, we mapped auxin signaling behavior using the genetically encoded markers R2D2 and DR5v2 ${ }^{16}$. R2D2 is based on a fusion of the auxin-dependent degradation domain II of an Aux/IAA protein to Venus fluorescent protein, and uses a mutated, non-degradable domain II linked to tdTomato as an internal control ${ }^{16}$. Hence, R2D2 signal is dictated by the levels of auxin as well as the endogenous receptors and represents a proxy for the auxin signaling input for every cell. Following multispectral live-cell image acquisition in plants carrying R2D2, we used computational analysis of the green to red ratio to determine the cellular auxin input status. We found that auxin is present and sensed fairly uniformly across the SAM including the central stem cell domain, with local minima only detected at organ boundaries (Fig. 1a, b and refs. 17,18). In contrast, DR5v2, a reporter for auxin signaling output based on a synthetic promoter containing repeats of ARF DNA binding motifs, was strongly activated non-uniformly in wedge shaped zones of differentiation competent cells, but only weakly expressed the center of the SAM (Fig. 1d; ref. 17). To spatially correlate cellular auxin output status with stem cell fate, we combined the DR5v2 reporter with a pCLV3:mCherry-NLS marker in a single transgenic line. Computational analysis of the DR5v2 and $p C L V 3$ signals revealed that the auxin response minimum invariantly coincided with the center of the stem cell domain (Fig. 1c-f).

To test if the auxin output minimum is functionally connected to stem cell identity, we interfered with their maintenance. To this end, we experimentally induced symplastic isolation through callose deposition at plasmodesmata of stem cells, which we had shown earlier to induce their differentiation" ${ }^{5,19}$. Following DR5v2 signal over time, we observed activation of auxin signaling output in the central zone domain after 36 hours of callose synthase (iCalSm) expression. In addition, cell expansion, a hallmark of plant cell differentiation, became obvious after 72 hours (Fig. 2a-d). All plants that exhibited stem cell loss following to iCalSm activation showed this pattern, which also led to a significant increase in DR5v2 signal intensity over time, in contrast to controls that did not respond (Fig. 2e-g; Supplementary Fig. 1).

Thus, stem cell fate and the auxin response minimum appeared to be functionally connected, leading us to hypothesize that manipulation of auxin signaling 
in the central zone should affect stem cell behavior. To test this directly, we designed a transgene to suppress auxin signaling output specifically in stem cells. Therefore, we fused the dominant auxin signaling output inhibitor BDL-D (IAA12) with the glucocorticoid receptor tag. The activity of the resulting fusion protein could be induced by dexamethasone (DEX) treatment, which allowed the translocation of BDL-D-GR from the cytoplasm to the nucleus, its native cellular compartment ${ }^{20}$. In line with our expectations, we found that inducing $p C L V 3: B D L-D-G R$ led to an expansion of the DR5v2 minimum in the center of the SAM reflecting the inhibitory activity of BDL-D on ARF transcription factors (Fig. 3a, b). Surprisingly, long term induction of BDL-D-GR or stem cell specific expression of $B D L-D$ without the GR tag caused meristem termination in about half of the seedlings ( $n=90$; Fig. $3 f, g$ ), demonstrating that stem cells require active auxin signaling for their maintenance. In contrast, expression of a potent positive signaling component, the auxin response factor ARF5/MONOPTEROS $(M P)$, or its constitutively active form MPA, which engages the auxin pathway independently of signal perception ${ }^{21}$, did not cause relevant reduction in meristem size (Fig. 3c-e, h, j and ref. 15). When expressed throughout the entire SAM by the HMG promoter (Supplementary Fig. 2a, b), MPA stimulated ectopic organ initiation specifically in the peripheral zone (Fig. 3i), demonstrating that resistance to auxin was not a general feature of the meristem, but limited to stem cells. Importantly, the DR5v2 reporter, which senses auxin output by providing binding sites for ARF transcription factors, was activated in stem cells of plants expressing MP and MP $\triangle$ (6/8 independent T1 lines) (Fig. 3c-e and Supplementary Fig. 2c-k), suggesting that the resistance to auxin occurs, at least in part, downstream of ARF activity. Taken together, these experiments demonstrated that auxin signaling is locally gated to permit a low instructive output level, while at the same time protecting stem cells from the differentiation inducing effects of the phytohormone at high signaling levels.

\section{WUSCHEL controls auxin signaling output in stem cells}

Since suppressing auxin signaling output in stem cell caused SAM arrest and a phenotype highly similar to wus mutants (Fig. $3 f, g$ ), we tested the contribution of WUS to controlling auxin responses in diverse genetic backgrounds. The WUS expression domain is massively enlarged in $c / v$ mutants ${ }^{1,2}$, which causes stem cell over-proliferation phenotypes, and therefore SAMs from these plants provide an ideal background to elucidate the functional connection of WUS and auxin. Consequently, we analyzed auxin output in c/v3 meristems and found the DR5v2 minimum expanded 
in line with the overaccumulation of WUS, however some weak signal remained throughout the SAM (Fig. 4a, b). To test whether auxin signaling is required for stem cell over-proliferation in c/v3 mutants, we locally blocked auxin output by our $p C L V 3: B D L-D$ transgene and observed stem cell termination phenotypes in almost all seedlings ( $n=30$; Fig. 4c). This result suggested that also in fasciated SAMs of $c / v 3$ mutants, ectopic WUS is sufficient to reduce auxin signaling, while at the same time permitting basal output levels. To test the short term effect of enhancing WUS levels without the indirect effects of the clv3 phenotype, we created plants that carry a pUBI10:mCherry-GR-linker-WUS (WUS-GR) transgene which allowed for experimental induction of ubiquitous WUS activity. After $24 \mathrm{~h}$ of DEX treatment the central auxin signaling minimum as well as the CLV3 domain expanded (Fig. 4d-f; Supplementary Fig. 3a-f), suggesting that WUS is indeed sufficient to reduce signaling output in the center of the SAM, but is unable to override active auxin responses at the periphery. To test whether WUS is also required to protect stem cells from high signaling levels, which lead to differentiation, we developed a genetic system that allowed us to inducibly degrade WUS protein in stem cells. To this end, we adapted deGradFP technology 22 and combined switchable stem cell specific expression of an anti-GFP nanobody with a pWUS:WUS-linker-GFP wus rescue line ${ }^{5}$. After $24 \mathrm{~h}$ induction of nanobody expression, WUS-linker-GFP signal was substantially reduced in stem cells of the epidermis and subepidermis (Fig. $4 \mathrm{~g}-\mathrm{h}$ ) and after five days we observed shoot termination (Fig. 4i). Combining this wus/pWUS:WUS-linkerGFP/pCLV3:AlcR/pAlcA:NSImb-vhhGFP4 line with the DR5v2 marker showed that after $24 \mathrm{~h}$ of WUS depletion, cells in center of the SAM had become responsive to auxin whereas they remained insensitive in mock treated controls (Fig. 4j-I). We made similar observations in plants carrying DR5v2 and the weak wus-7 allele, which were able to maintain a functional SAM for some time and only terminated stochastically. In these lines, DR5v2 activity fluctuated substantially and was frequently observed in the central zone (Fig. $4 \mathrm{I}$ and Supplementary Fig. 4). Taken together, these results demonstrated that WUS is required to rheostatically maintain stem cells in a state of low auxin signaling. 


\section{Mechanisms of auxin pathway gating}

To address how WUS is able to control the output of the auxin pathway, we went on to define direct target genes combining new ChIP-seq and RNA-seq experiments using seedlings of our WUS-GR line. Leveraging the uniform expression and high inducibility of our transgene, as well as the high affinity of RFP-trap single chain antibodies to the mCherry tag used for our ChIP protocol, we were able to identify 6740 genomic regions bound by WUS. This compared to 136 regions we had previously identified by ChIP-chip ${ }^{23}$. Previously identified direct targets, such as $A R R 7$, CLV1, KAN1, KAN2 AS2 and YAB3 (refs. 23-25) were also picked up in our new datasets. Interestingly, WUS binding was almost exclusively found in regions of open chromatin ${ }^{26}$ and among the WUS targets we found the gene ontology term "response to auxin" to be most highly enriched within the developmental category (Supplementary Table 1). Importantly, WUS appeared to control auxin signaling output at all relevant levels, since it was able to bind to the promoters or regulate the expression of a large number of genes involved in auxin transport, auxin perception, auxin signal transduction, as well as auxin response, which occurs downstream of ARF transcription factors (Fig. 5a and Supplementary Table 2). Since WUS can act as transcriptional activator or repressor dependent on the regulatory environment 27,28 and our profiling results were based on ectopic expression of WUS in non-stem cells, we were unable to predict how the expression of individual targets would be affected in vivo. However, it has been reported that in the SAM, WUS mainly acts as a transcriptional repressor ${ }^{23-25,27}$ and consistently, many auxin signaling components are expressed at high levels only in the periphery of the SAM and exhibit low RNA accumulation in the cells that are positive for WUS protein ${ }^{17}$. To test if WUS is required for this pattern, we analyzed the response of MP and TIR1 mRNA accumulation to variations in WUS expression. To circumvent morphological defects of stable wus mutants, we again made use of our deGradFP line to analyze expression of MP after loss of WUS protein activity, but prior to changes in SAM morphology. After $24 \mathrm{~h}$ of WUS depletion, MP mRNA expression had extended from the periphery into the central zone (Fig. 5b, c; Supplementary Fig. 5), demonstrating that WUS is indeed required for MP repression in stem cells. Conversely, ectopic activation of WUS revealed that it is also sufficient to reduce, but not shut down MP and TIR1 transcription even in the periphery of the SAM (Fig. 5d-e, Supplementary Fig. $3 g, \mathrm{~h}$ ).

To elucidate the molecular mechanisms responsible for the observed rheostatic activity, we asked whether chromatin structure may be changed in response 
to WUS. WUS physically interacts with TOPLESS (TPL) ${ }^{29,30}$, a member of the GROUCHO/Tup1 family of transcriptional co-repressors. These adaptor proteins mediate interaction with HISTONE DEACETYLASES (HDACs, reviewed in 31), which in turn act to reduce transcriptional activity of chromatin regions via promoting the removal of acetyl modifications from histone tails ${ }^{32}$. To test whether regulation of chromatin modification is involved in translating WUS activity into the observed reduction of transcriptional activity of target genes we quantified histone acetylation on H3K9/K14 and methylation on H3K27. After $2 \mathrm{~h}$ of induction of our WUS-GR line, we observed a significant change in the genome wide histone acetylation patterns, which were spatially correlated with WUS chromatin binding events (2939 out of 6740 WUS bound chromatin regions showed acetylation changes), while histone methylation patterns were largely unaffected (634 out of 6740 WUS bound chromatin regions showed methylation changes) (Fig. 6a). WUS binding events clustered in the proximal promoter regions, while chromatin regions whose acetylation levels were changed after WUS activation were mainly found around the transcriptional start sites and 5'UTRs of genes (Fig. 6b). Zooming in on the 1656 directly repressed WUS targets, we found that 587 of them also showed histone de-acetylation. For the vast majority of these loci the observed reduction was fairly subtle, suggesting that mild deacetylation may be the mechanism that allows WUS to reduce, but not shut off transcription of target genes. To test whether the observed changes in chromatin state of direct WUS targets also translate to variation in gene expression, we induced WUS activity in the absence or presence of Trichostatin A (TSA), a potent inhibitor of class I and II HDACs ${ }^{33}$, and recorded the transcriptional response. Principle Component Analysis (PCA) not only showed that both WUS activation and TSA contributed to gene expression variance, but that there was a clear interaction of their activities. Strikingly, roughly $40 \%$ of gene expression variance caused by WUS activation was suppressed by TSA treatment (Fig. 6c). Consistently, from the 1656 directly repressed genes, 938 were no longer responsive to WUS-GR induction when TSA was present and roughly a third of them showed significant reduction in H3K9/K14 acetylation levels (Fig. 6d). These results underlined the relevance of histone de-acetylation for the genome-wide functional output of WUS and prompted us to investigate whether this mechanism is relevant for controlling auxin responses in the SAM. Therefore, we analyzed DR5v2 reporter activity after TSA and/or auxin treatment and found that auxin was insufficient to trigger a transcriptional response in stem cells, likely due to the presence of functional WUS (Fig. 6e). In contrast, inactivation of HDACs and consequently WUS- 
mediated transcriptional repression by TSA treatment, led to low but consistent DR5v2 signal in the center of the meristem (Fig. 6f). Finally, combining a reduction in WUS function by TSA with stimulation of the auxin pathway caused a substantial DR5v2 response in stem cells (Fig. 6g). Taken together, these results showed that WUS binds to and reduces transcription of the majority of genes involved in auxin signaling and response via de-acetylation of histones and thus is able to rheostatically maintain pathway activity in stem cells at a basal level.

\section{Pathway wide control provides robustness to apical stem cell fate}

We next wondered what the functional relevance of the observed pathway wide regulatory interaction might be. Therefore, we tested the capacity of WUS targets with auxin signaling or response functions to interfere with stem cell activity. Based on their highly localized expression at the periphery of the SAM ${ }^{17}$, we selected the signaling components ARF3, ARF4, ARF5 (MP), IAA8, IAA9, and IAA12 (BDL) as well as the TIR1 receptor along with transcription factors of the auxin response category including TARGET OF MONOPTEROS (TMO) and LATERAL ORGAN BOUNDARIES (LOB) genes that have established roles in other developmental contexts ${ }^{34}$. Neither of the 17 factors tested caused meristem phenotypes when expressed in stem cells (Fig. 2 and Table 1), highlighting the robustness of stem cell fate in the presence of WUS on the one hand and the activity of auxin signaling in these cells on the other hand. This conclusion is based on two observations: 1 . The auxin sensitive native version of BDL was unable to terminate the SAM in contrast to the auxin insensitive BDL-D version (Fig. 3f, g). 2. pCLV3:MP plants showed enhanced DR5v2 activity in stem cells (Fig. 3c, d) demonstrating that ARF activity is indeed limiting for transcriptional output in wild-type. However, the transcriptional output registered by the DR5v2 reporter was not translated into an auxin response, since WUS limited the expression of a large fraction of the required downstream genes (Fig. 5a; Supplementary Table 2). Thus, WUS seems to act both up- and downstream of the key ARF transcription factors.

Since we had found that stem cell specific expression of individual auxin signaling components was not sufficient to interfere with stem cell fate, we wanted to test whether reducing WUS function would sensitize stem cells to activation of the entire pathway. To this end, we grew plants segregating for wus-7 on plates supplemented with auxin. Eleven days after germination, we observed twice as many terminated wus-7 mutant seedlings on auxin plates compared to control plates, whereas wild-type seedlings were unaffected (Fig. 6h). Thus, reducing WUS function 
allowed activation of auxin responses under conditions that were tolerated in wild type. Taken together, the activation of individual pathway components was insufficient to override the protective effect of WUS, however compromising the master regulator itself rendered stem cells vulnerable to even mild perturbations in auxin signaling.

\section{Discussion}

In conclusion, our results show that WUS restricts auxin signaling in apical stem cells by pathway-wide transcriptional control, while at the same time allowing instructive low levels of signaling output. This rheostatic activity may be based on selective transcriptional repression/activation of a subset of signaling and response components that render the pathway unresponsive to high input levels. Alternatively, WUS may be able to reduce expression of targets rather than to shut off their activity completely, leaving sufficient capacity for low level signaling only. In support of the latter hypothesis, we demonstrate that WUS acts via de-acetylation of histones and that interfering with HDAC activity triggers auxin responses in stem cells. However, there is evidence supporting both scenarios ${ }^{23,25,27,28}$ and likely both mechanisms work hand in hand dependent on the regulatory environment of the individual cell. Thus, a definitive answer will require inducible WUS loss of function approaches in stem cells coupled with time-resolved whole genome transcript profiling at the single cell level. Importantly, in addition to its effects on auxin signaling, WUS enhances cytokinin responses via the repression of negative feedback regulators ${ }^{24}$. This interaction can be overridden by expression of constitutively active versions of these negative feedback components ${ }^{24}$, and similarly we find here that dominant negative auxin regulators lead to SAM arrest. In contrast, wild-type or constitutively active auxin signaling elements do not lead to SAM defects, suggesting that WUS acts primarily to limit auxin responses. Thus, by acting on both pathways by direct reduction of target gene expression, WUS protects stem cells from auxin mediated differentiation, while at the same time enhancing cytokinin output, which may primarily serve to sustain WUS expression ${ }^{35,36}$. Auxin and cytokinin signaling are directly coupled also in other stem cell systems and balancing their outputs is key to maintaining functional plant stem cell niches ${ }^{15,37}$. Given the dynamic and self-organizing nature of the auxin system in the $\mathrm{SAM}^{38}$, the independent spatial input provided by WUS appears to be required to bar differentiation competence from the center of the SAM, while at the same time still allowing to sense this important signal. In light of the findings that PIN1 mediated auxin flux in the SAM may be directed towards the center ${ }^{39}$, it is tempting to speculate 
that auxin could serve as a positional signal not only for organ initiation, but also for stem cells.

\section{Author Contributions:}

A. Me. performed in situ hybridizations, C.W. carried out imaging and analyses, J.F. established the WUS-GR line, G.U. and A. M. performed RNA-seq, O.E. performed bioinformatic analyses, K.B. and T.G. established the pDR5v2:ER-EYFPHDEL:tAt4g24550 line, C.G. made the pCLV3:mCherry-NLS:tCLV3 construct, Z.Š., A.M and Y.M. performed all other experiments. C.G.-A. and T.V. designed the TSA treatment of the SAM, Y.M., Z.Š., A.M. and J.U.L. designed all other experiments and wrote the paper with input from all other authors. Sequencing data is available under GEO accession GSE122611.

\section{Acknowledgments:}

We thank Dolf Weijers for sharing R2D2 and DR5v2 resources before publication. This work was supported by the DFG through grants SFB1101 and SFB873 to JUL and TG and by HFSP Grant RPG0054-2013 and ANR-12-BSV6-0005 grant to T.V. Computational analyses have been carried out on heiCLOUD provided by Heidelberg University Computing Centre. 


\section{References}

1. Schoof, $H$. et al. The stem cell population of Arabidopsis shoot meristems in maintained by a regulatory loop between the CLAVATA and WUSCHEL genes. Cell 100, 635-644 (2000).

2. Brand, U., Fletcher, J. C., Hobe, M., Meyerowitz, E. M. \& Simon, R. Dependence of stem cell fate in Arabidopsis on a feedback loop regulated by CLV3 activity. Science 289, 617-619 (2000).

3. Mayer, K. F. et al. Role of WUSCHEL in regulating stem cell fate in the Arabidopsis shoot meristem. Cell 95, 805-815 (1998).

4. Yadav, R. K. et al. WUSCHEL protein movement mediates stem cell homeostasis in the Arabidopsis shoot apex. Genes Dev 25, 2025-2030 (2011).

5. Daum, G., Medzihradszky, A., Suzaki, T. \& Lohmann, J. U. A mechanistic framework for noncell autonomous stem cell induction in Arabidopsis. Proc Natl Acad Sci USA 111, 14619-14624 (2014).

6. Laux, T., Mayer, K. F., Berger, J. \& Jürgens, G. The WUSCHEL gene is required for shoot and floral meristem integrity in Arabidopsis. Development 122, 87-96 (1996).

7. Benjamins, R. \& Scheres, B. Auxin: the looping star in plant development. Annu Rev Plant Biol 59, 443-465 (2008).

8. Kepinski, S. \& Leyser, O. Auxin-induced SCFTIR1-Aux/IAA interaction involves stable modification of the SCFTIR1 complex. Proc. Natl. Acad. Sci. U.S.A. 101, 12381-12386 (2004).

9. Dharmasiri, N., Dharmasiri, S. \& Estelle, M. The F-box protein TIR1 is an auxin receptor. Nature 435, 441-445 (2005).

10. Kepinski, S. \& Leyser, O. The Arabidopsis F-box protein TIR1 is an auxin receptor. Nature 435, 446-451 (2005).

11. Vernoux, T., Kronenberger, J., Grandjean, O., Laufs, P. \& Traas, J. PINFORMED 1 regulates cell fate at the periphery of the shoot apical meristem. Development 127, 5157-5165 (2000).

12. Reinhardt, D. et al. Regulation of phyllotaxis by polar auxin transport. Nature 426, 255-260 (2003).

13. Luo, L., Zeng, J., Wu, H., Tian, Z. \& Zhao, Z. A Molecular Framework for Auxin-Controlled Homeostasis of Shoot Stem Cells in Arabidopsis. Mol Plant 11, 899-913 (2018).

14. Shi, B. et al. Feedback from Lateral Organs Controls Shoot Apical Meristem Growth by Modulating Auxin Transport. Dev Cell 44, 204-216.e6 (2018).

15. Zhao, Z. et al. Hormonal control of the shoot stem-cell niche. Nature 465, 1089-1092 (2010).

16. Liao, C.-Y. et al. Reporters for sensitive and quantitative measurement of auxin response. Nature Methods 12, 207-210 (2015).

17. Vernoux, T. et al. The auxin signalling network translates dynamic input into robust patterning at the shoot apex. Mol Syst Biol 7, 508 (2011).

18. Brunoud, G. et al. A novel sensor to map auxin response and distribution at high spatio-temporal resolution. Nature 482, 103-106 (2012).

19. Vatén, A. et al. Callose biosynthesis regulates symplastic trafficking during root development. Dev Cell 21, 1144-1155 (2011).

20. Lloyd, A. M., Schena, M., Walbot, V. \& Davis, R. W. Epidermal cell fate determination in Arabidopsis: patterns defined by a steroid-inducible regulator. Science 266, 436-439 (1994). 
21. Hardtke, C. S. \& Berleth, T. The Arabidopsis gene MONOPTEROS encodes a transcription factor mediating embryo axis formation and vascular development. EMBO J 17, 1405-1411 (1998).

22. Caussinus, E., Kanca, O. \& Affolter, M. Fluorescent fusion protein knockout mediated by anti-GFP nanobody. Nature Publishing Group 19, 117-121 (2011).

23. Busch, W. et al. Transcriptional control of a plant stem cell niche. Dev Cell 18, 849-861 (2010).

24. Leibfried, A. et al. WUSCHEL controls meristem function by direct regulation of cytokinin-inducible response regulators. Nature 438, 1172-1175 (2005).

25. Yadav, R. K. et al. Plant stem cell maintenance involves direct transcriptional repression of differentiation program. Mol Syst Biol 9, 654-654 (2013).

26. Zhang, W., Zhang, T., Wu, Y. \& Jiang, J. Genome-wide identification of regulatory DNA elements and protein-binding footprints using signatures of open chromatin in Arabidopsis. Plant Cell 24, 2719-2731 (2012).

27. Ikeda, M., Mitsuda, N. \& Ohme-Takagi, M. Arabidopsis WUSCHEL is a bifunctional transcription factor that acts as a repressor in stem cell regulation and as an activator in floral patterning. Plant Cell 21, 3493-3505 (2009).

28. Zhou, Y. et al. HAIRY MERISTEM with WUSCHEL confines CLAVATA3 expression to the outer apical meristem layers. Science 361, 502-506 (2018).

29. Long, J. A., Ohno, C., Smith, Z. R. \& Meyerowitz, E. M. TOPLESS regulates apical embryonic fate in Arabidopsis. Science 312, 1520-1523 (2006).

30. Kieffer, M. et al. Analysis of the transcription factor WUSCHEL and its functional homologue in Antirrhinum reveals a potential mechanism for their roles in meristem maintenance. Plant Cell 18, 560-573 (2006).

31. Liu, Z. \& Karmarkar, V. Groucho/Tup1 family co-repressors in plant development. Trends Plant Sci 13, 137-144 (2008).

32. Taunton, J., Hassig, C. A. \& Schreiber, S. L. A mammalian histone deacetylase related to the yeast transcriptional regulator Rpd3p. Science 272, 408-411 (1996).

33. Yoshida, M., Kijima, M., Akita, M. \& Beppu, T. Potent and specific inhibition of mammalian histone deacetylase both in vivo and in vitro by trichostatin $A$. $J$ Biol Chem 265, 17174-17179 (1990).

34. Schlereth, A. et al. MONOPTEROS controls embryonic root initiation by regulating a mobile transcription factor. Nature 464, 913-916 (2010).

35. Gordon, S. P., Chickarmane, V. S., Ohno, C. \& Meyerowitz, E. M. Multiple feedback loops through cytokinin signaling control stem cell number within the Arabidopsis shoot meristem. Proceedings of the National Academy of Sciences 106, 16529-16534 (2009).

36. Buechel, S. et al. Role of A-type ARABIDOPSIS RESPONSE REGULATORS in meristem maintenance and regeneration. European Journal of Cell Biology 89, 279-284 (2010).

37. Müller, B. \& Sheen, J. Cytokinin and auxin interaction in root stem-cell specification during early embryogenesis. Nature 453, 1094-1097 (2008).

38. Bhatia, N. et al. Auxin Acts through MONOPTEROS to Regulate Plant Cell Polarity and Pattern Phyllotaxis. Curr Biol 26, 3202-3208 (2016).

39. Galvan-Ampudia, C. S. et al. From spatio-temporal morphogenetic gradients to rhythmic patterning at the shoot apex. bioRxiv 1-16 (2018). doi: $10.1101 / 469718$

40. Yadav, R. K., Tavakkoli, M., Xie, M., Girke, T. \& Reddy, G. V. A highresolution gene expression map of the Arabidopsis shoot meristem stem cell niche. Development 141, 2735-2744 (2014). 
41. Yadav, R. K., Girke, T., Pasala, S., Xie, M. \& Reddy, G. V. Gene expression map of the Arabidopsis shoot apical meristem stem cell niche. Proc Natl Acad Sci USA 106, 4941-4946 (2009).

42. Prunet, N. Live Confocal Imaging of Developing Arabidopsis Flowers. $J$ Vis Exp e55156-e55156 (2017). doi:10.3791/55156

43. Roslan, H. A. et al. Characterization of the ethanol-inducible alc geneexpression system in Arabidopsis thaliana. 28, 225-235 (2001).

44. Lampropoulos, A. et al. GreenGate---a novel, versatile, and efficient cloning system for plant transgenesis. PLoS ONE 8, e83043 (2013).

45. Schindelin, J. et al. Fiji: an open-source platform for biological-image analysis. Nat Meth 9, 676-682 (2012).

46. de Reuille, P. B., Robinson, S. \& Smith, R. S. Quantifying cell shape and gene expression in the shoot apical meristem using MorphoGraphX. Methods $\mathrm{Mol}$ Biol 1080, 121-134 (2014).

47. Sommer, C., Straehle, C., Kothe, U. \& Hamprecht, F. A. Ilastik: Interactive learning and segmentation toolkit. in 230-233 (IEEE, 2011). doi:10.1109/ISBI.2011.5872394

48. Berthold, M. R. et al. KNIME - the Konstanz information miner: version 2.0 and beyond. ACM SIGKDD Explorations Newsletter 11, 26-31 (2009).

49. Medzihradszky, A., Schneitz, K. \& Lohmann, J. U. Detection of mRNA expression patterns by nonradioactive in situ hybridization on histological sections of floral tissue. Methods Mol Biol 1110, 275-293 (2014).

50. Pfeiffer, A. et al. Integration of light and metabolic signals for stem cell activation at the shoot apical meristem. Elife 5, 827 (2016).

51. Li, H. \& Durbin, R. Fast and accurate short read alignment with BurrowsWheeler transform. Bioinformatics 25, 1754-1760 (2009).

52. Afgan, E. et al. The Galaxy platform for accessible, reproducible and collaborative biomedical analyses: 2018 update. Nucleic Acids Res 46, W537W544 (2018).

53. Starmer, J. \& Magnuson, T. Detecting broad domains and narrow peaks in ChIP-seq data with hidden Domains. BMC Bioinformatics 17, 144 (2016).

54. Huang, W., Loganantharaj, R., Schroeder, B., Fargo, D. \& Li, L. PAVIS: a tool for Peak Annotation and Visualization. Bioinformatics 29, 3097-3099 (2013).

55. Kim, D., Langmead, B. \& Salzberg, S. L. HISAT: a fast spliced aligner with low memory requirements. Nat Meth 12, 357-360 (2015).

56. Liao, Y., Smyth, G. K. \& Shi, W. featureCounts: an efficient general purpose program for assigning sequence reads to genomic features. Bioinformatics 30 , 923-930 (2014).

57. Love, M. I., Huber, W. \& Anders, S. Moderated estimation of fold change and dispersion for RNA-seq data with DESeq2. Genome Biol 15, 550 (2014). 
Figures and Legends:
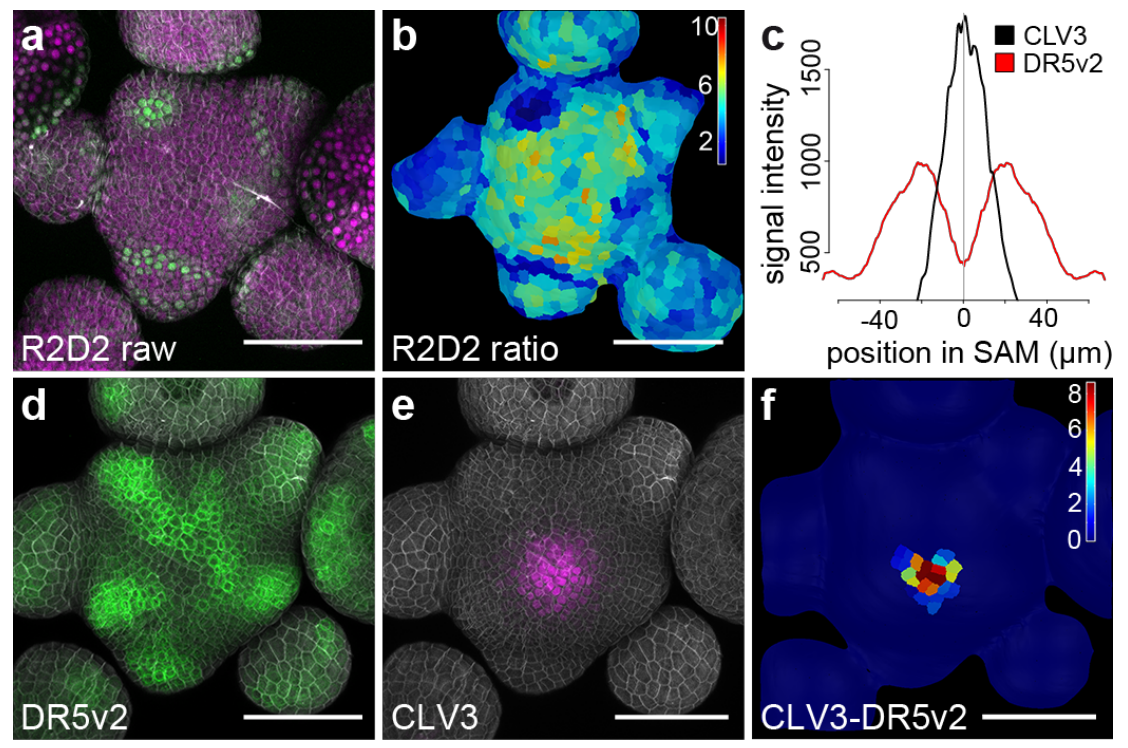

Figure 1: Auxin output minimum correlates with apical stem cells.

a) Confocal readout from R2D2 auxin input sensor. b) Ratiometric representation of R2D2 activity in the epidermal cell layer (L1). c) Quantification of averaged pDR5V2:ER-eYFP-HDEL and pCLV3:mCherry-NLS distribution $(\mathrm{n}=5) . \mathbf{d})$ Confocal readout from $p D R 5 v 2: E R-e Y F P-H D E L$ auxin output reporter. e) $p C L V 3: m C h e r r y-N L S$ stem cell marker in the same SAM. f) Computational subtraction of L1 signals shown in (d) and (e). Relative signal intensity is shown in arbitrary units. Scale bars: $50 \mu \mathrm{m}$. 


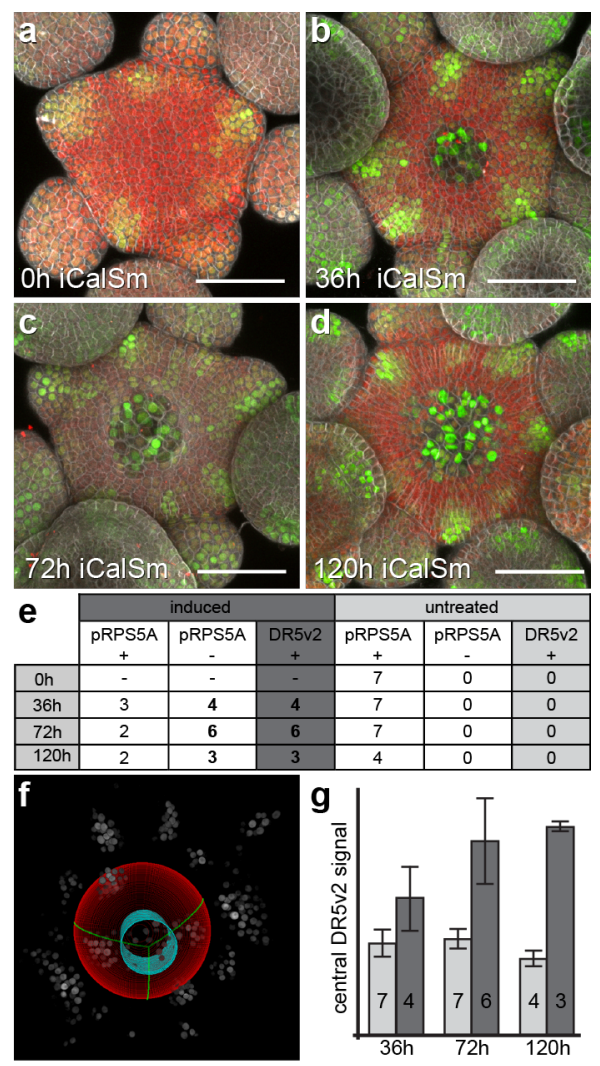

Fig. 2: The central auxin signaling minimum is dependent on stem cell fate.

a-d) $p D R 5 v 2: 3 x$ VENUS-NLS activity after induction of iCalSm. Stem cell differentiation is marked by loss of pRPS5a:NLS-tdTomato. e) Quantification of DR5v2 response to induction of iCalSm at the per plant level. Number of plants scored for loss of RPS5a promoter activity from stem cells and DR5v2 expression are shown. Stem cell loss and associated DR5v2 activation exclusively occurred in induced plants. All plants with stem cell loss as shown by reduced pRPS5a activity expressed DR5v2. pRPS5a + denotes plants with uncompromised $p R P S 5$ a promoter activity in stem cells. $p R P S 5 a$ - denotes plants with reduced pRPS5a promoter activity in stem cells. DR5v2 + denotes plants with DR5v2 activity in stem cells. f) Computational sphere fitting and identification of the central zone for fluorescence signal quantification. g) Quantification of DR5v2 signal intensity in the central zone across the experimental cohort described in (e). Light grey bars represent uninduced controls, dark grey bars represent plants induced with $1 \%$ ethanol. Numbers of analyzed SAMs are indicated. See also Supplementary Figure 1. 

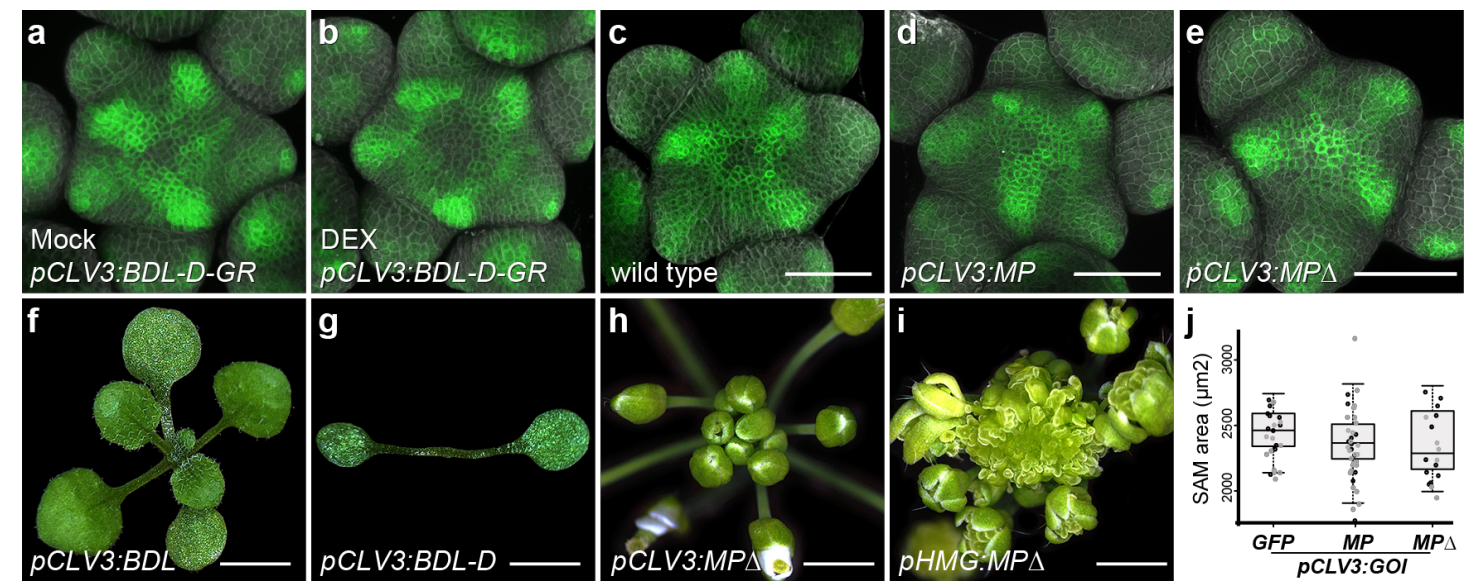

Fig. 3: Stem cells require auxin signaling, but are resistant to overactivation of the pathway.

a-e) $p D R 5 V 2: E R$-eYFP-HDEL activity in plants harboring $p C L V 3: B D L-D-G R$ after $24 \mathrm{~h}$ of mock treatment (A), pCLV3:BDL-D-GR after 24h of DEX treatment (B), wild type (C), pCLV3:MP (D) or pCLV3:MPA (E). f-i) Representative phenotypes of lines expressing $p C L V 3: B D L(\mathrm{~F}), p C L V 3: B D L-D(\mathrm{G}), p C L V 3: M P \triangle(\mathrm{H})$, or $p H M G: M P \Delta(\mathrm{I}) . \mathrm{j})$ SAM size quantifications for plants carrying $p C L V 3: G F P, p C L V 3: M P$, or $p C L V 3: M P \triangle$ in two independent T1 populations. All scale bars $50 \mu \mathrm{m}$, except $\mathrm{F}$ ) and $\mathrm{G}) 3,5 \mathrm{~mm} ; \mathrm{H}$ ) and I) $2 \mathrm{~mm}$. 

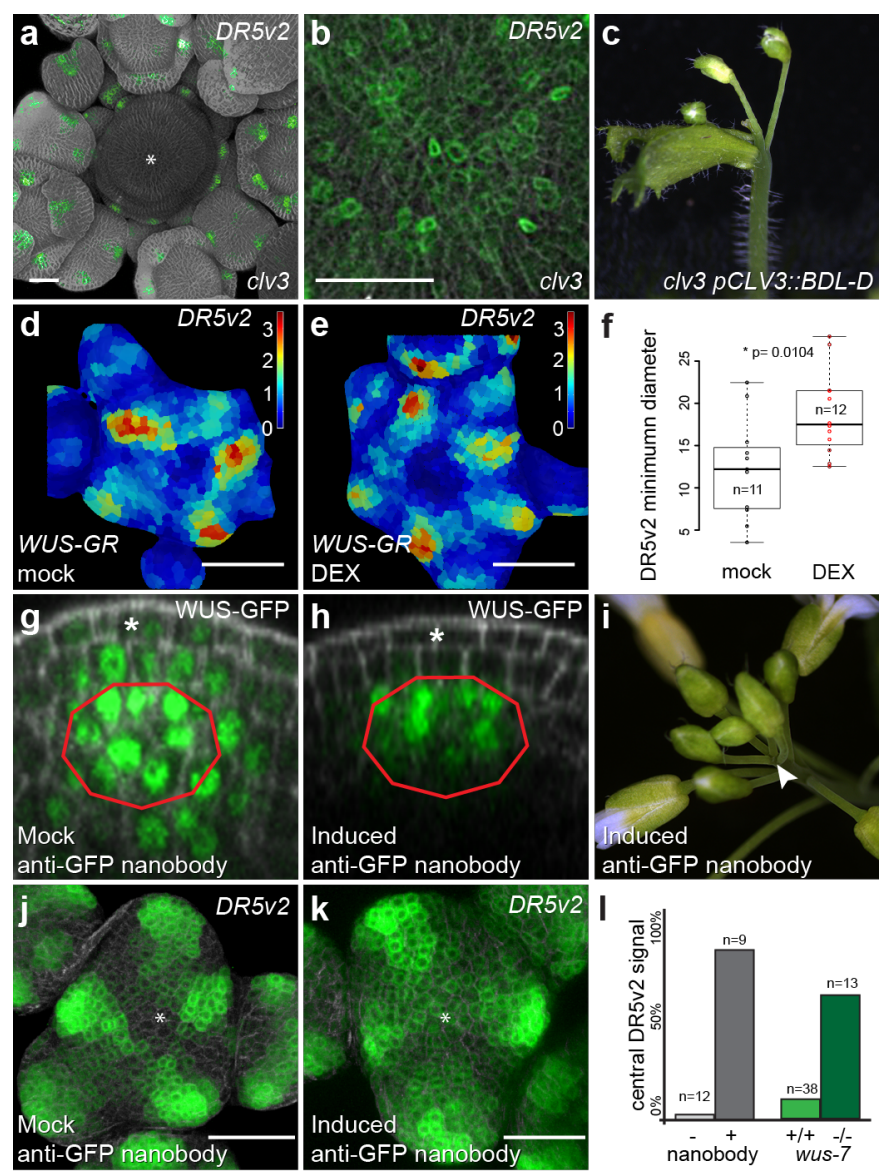

Fig. 4: WUSCHEL maintains low auxin signaling output in stem cells.

a) pDR5v2:ER-mCherry-HDEL activity in SAM of clv3 mutant. Asterisk marks center of SAM. b) Zoom into central SAM area of $c / v 3$ mutants reveals basal $p D R 5 v 2$ activity. c) SAM arrest caused by $p C L V 3: B D L-D$ expression in $c / v 3$. d, e) Representative pDR5v2:ER-mCherry-HDEL signals after $24 \mathrm{~h}$ of mock treatment (D) or inducible ectopic activation of WUS-GR activity (E). f) Quantification of central DR5v2 signal minimum following ectopic WUS activation. $\mathbf{g}, \mathbf{h}$ ) Representative images of a pWUS:WUS-linker-GFP rescue line expressing the anti GFP nanobody under the control of pCLV3:AlcR (wus/pWUS:WUS-linker-GFP/pCLV3:AlcR/pAlcA:NSImbvhhGFP4). g) WUS-linker-GFP signal after $24 \mathrm{~h}$ of mock treatment. h) WUS-linker-GFP signal after $24 \mathrm{~h}$ of WUS depletion. i) Shoot termination observed five days after WUS depletion. Red lines mark WUS mRNA expressing cells of the organizing centre; asterisk denote epidermal stem cells. j, k) Representative pDR5v2:ER-mCherry-HDEL signals after $24 \mathrm{~h}$ of mock treatment (D) or depletion of WUS protein from stem cells. I) Quantification of DR5v2 presence in the central zone following WUS depletion or in weak wus-7 mutants. Scale bars: $50 \mu \mathrm{m}$. 
a
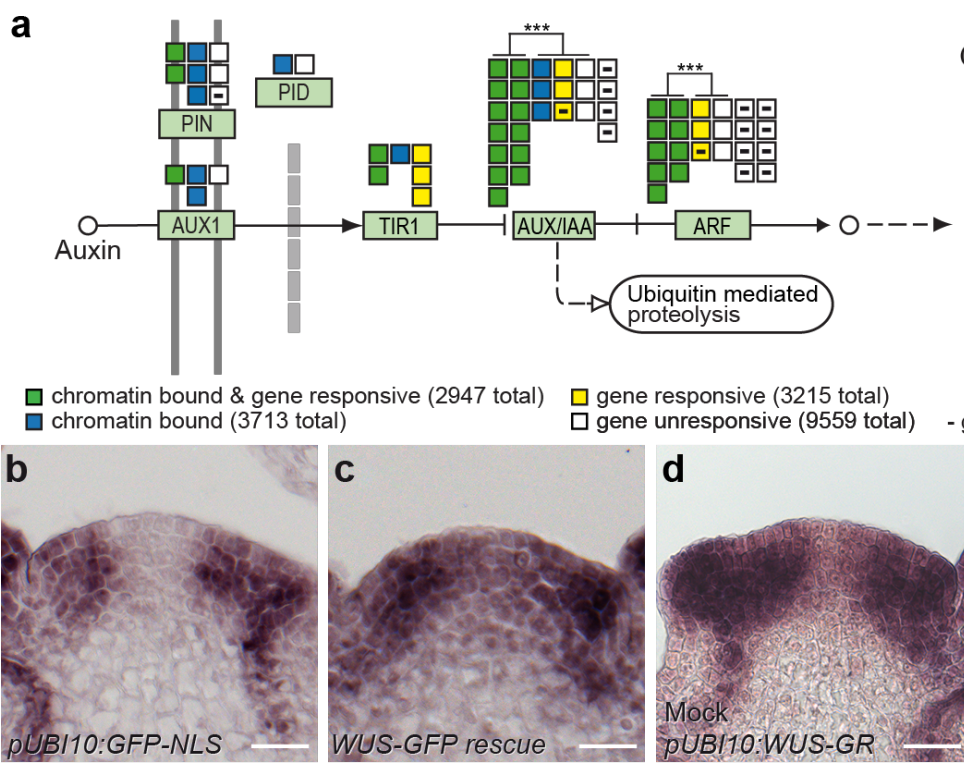

gene responsive ( 3215 total)

GO: response to auxin
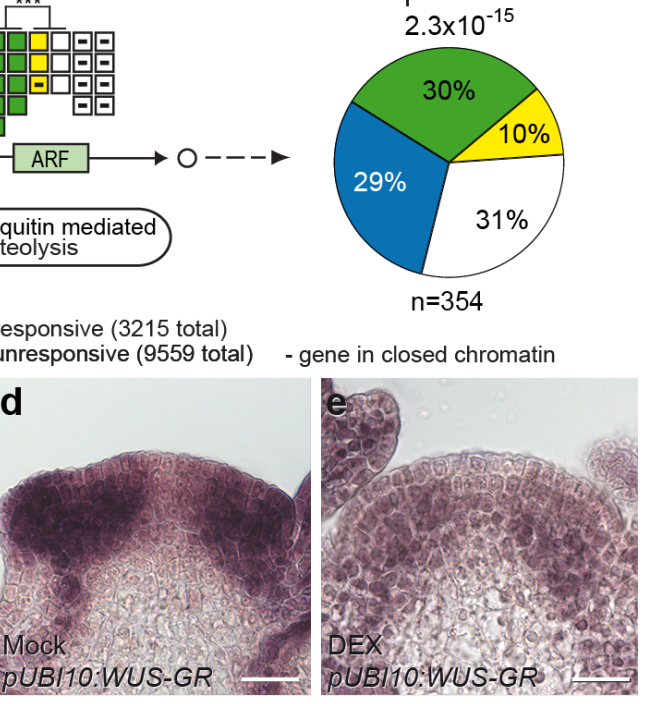

Fig. 5: Pathway level control underlies WUSCHEL mediated gating of auxin signaling.

a) WUS globally affects the auxin pathway, including transport, perception, signal transduction, as well as transcriptional response. Across the entire pathway bound and responsive genes are overrepresented ( $p$-value $\left.9.9^{*} 10^{-10}\right)$. Within gene family tests are shown. ${ }^{* * *} p$-value by Fisher exact test $<10^{-4}$. b, c) MP RNA accumulation 24 hours post anti-GFP nanobody induction in a pUB/10:GFP-NLS control line (B) and the pWUS:WUS-linker-GFP wus rescue background (C). d, e) Response of MP mRNA to ectopic activation of WUS-GR. MP RNA after $24 \mathrm{~h}$ of mock (D) or DEX treatment (E). Scale bars: $20 \mu \mathrm{m}$. 

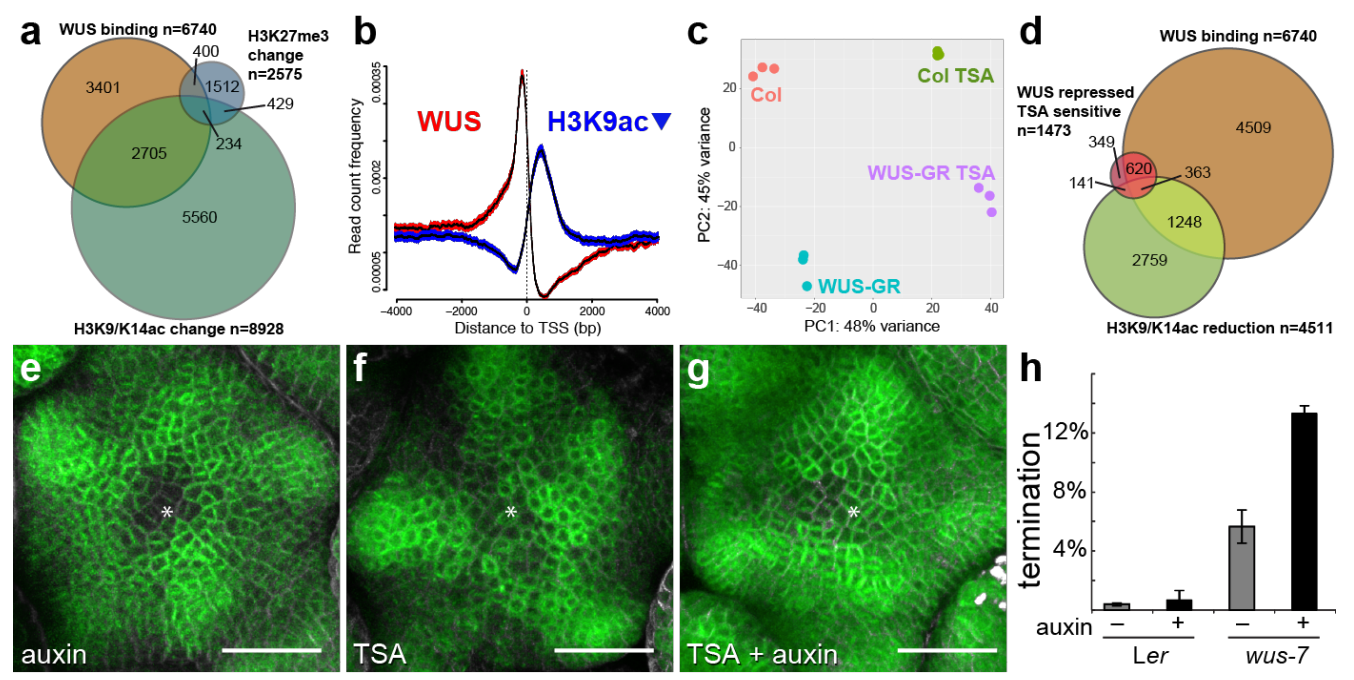

Fig. 6: WUS acts by regulating the histone acetylation status of target loci.

a) Venn diagram showing the overlap between WUS binding regions (orange), and loci with significant changes in H3K9K14ac (green) or H3K27me3 (blue) status. b) Spatial correlation between WUS chromatin binding events (red) and regions with reduced histone acetylation (blue) 0.95 confidence intervals are shown. c) PCA showing the global transcriptional response to WUS-GR activation in the presence or absence of TSA. TSA treatment suppressed almost $50 \%$ of gene expression variance caused by activation of WUS-GR. $\mathbf{d}$ ) Venn diagram showing the overlap between WUS binding regions (orange), and loci with significant reduction in H3K9K14ac (light green) and genes whose expression was reduced by WUS in a TSA sensitive manner (red). e-g) Representative images of pDR5v2:ER-mCherry-HDEL activity in response to HDAC inhibition. e) Auxin treated SAM; f) TSA treated SAM; g) TSA and auxin treated SAM. Asterisk denote center of the SAM. h) Quantification of terminated seedlings grown on auxin plates (10 $\mu \mathrm{M}$ IAA; $\mathrm{n}>200$ for each genotype and treatment). Genotyping revealed that all arrested plants were homozygous for wus-7. Scale bars: $30 \mu \mathrm{m}$. 


\begin{tabular}{|c|c|c|c|c|c|}
\hline AGI & Name & $\begin{array}{c}\text { Responsive } \\
\text { to auxin }\end{array}$ & $\begin{array}{c}\text { Expression } \\
\text { PZ }>C Z\end{array}$ & $\begin{array}{c}\text { Promoter bound } \\
\text { by WUS }\end{array}$ & $\begin{array}{c}\text { Responsive } \\
\text { to WUS }\end{array}$ \\
\hline AT3G62980 & TIR1 & $x$ & $x$ & $x$ & $x$ \\
\hline AT2G33860 & ARF3 & $x$ & $x$ & $x$ & $x$ \\
\hline AT5G60450 & ARF4 & $x$ & $\mathrm{x}$ & $\mathrm{x}$ & $\mathrm{x}$ \\
\hline AT1G19850 & ARF5 (MP) & $x$ & $x$ & $x$ & $x$ \\
\hline AT2G22670 & IAA8 & $x$ & $x$ & - & $x$ \\
\hline AT5G65670 & IAA9 & $x$ & $x$ & $x$ & $x$ \\
\hline AT1G04550 & $I A A 12(B D L)$ & $x$ & $x$ & - & - \\
\hline AT5G60200 & TMO6 & $x$ & $\mathrm{x}$ & $\mathrm{x}$ & $\mathrm{x}$ \\
\hline AT1G74500 & TMO7 & $x$ & - & - & - \\
\hline AT3G25710 & TMO5 & $x$ & - & - & $x$ \\
\hline AT4G23750 & TMO3 & $x$ & - & $x$ & $x$ \\
\hline AT1G68510 & $\angle B D 42$ & - & - & $x$ & - \\
\hline AT3G49940 & $\angle B D 38$ & - & - & $x$ & $x$ \\
\hline AT3G58190 & $\angle B D 29$ & $x$ & - & - & - \\
\hline AT3G11280 & & $x$ & $x$ & $x$ & $x$ \\
\hline AT3G28910 & МYB30 & $x$ & $x$ & $\mathrm{x}$ & $\mathrm{x}$ \\
\hline AT5G58900 & & $x$ & $x$ & $x$ & - \\
\hline
\end{tabular}

Table 1: WUS targets functionally tested by stem cell specific expression.

Expression domains in the SAM are based on refs. 17,40,41. 


\section{Supplementary Data}

\section{Supplementary Figures 1-5}
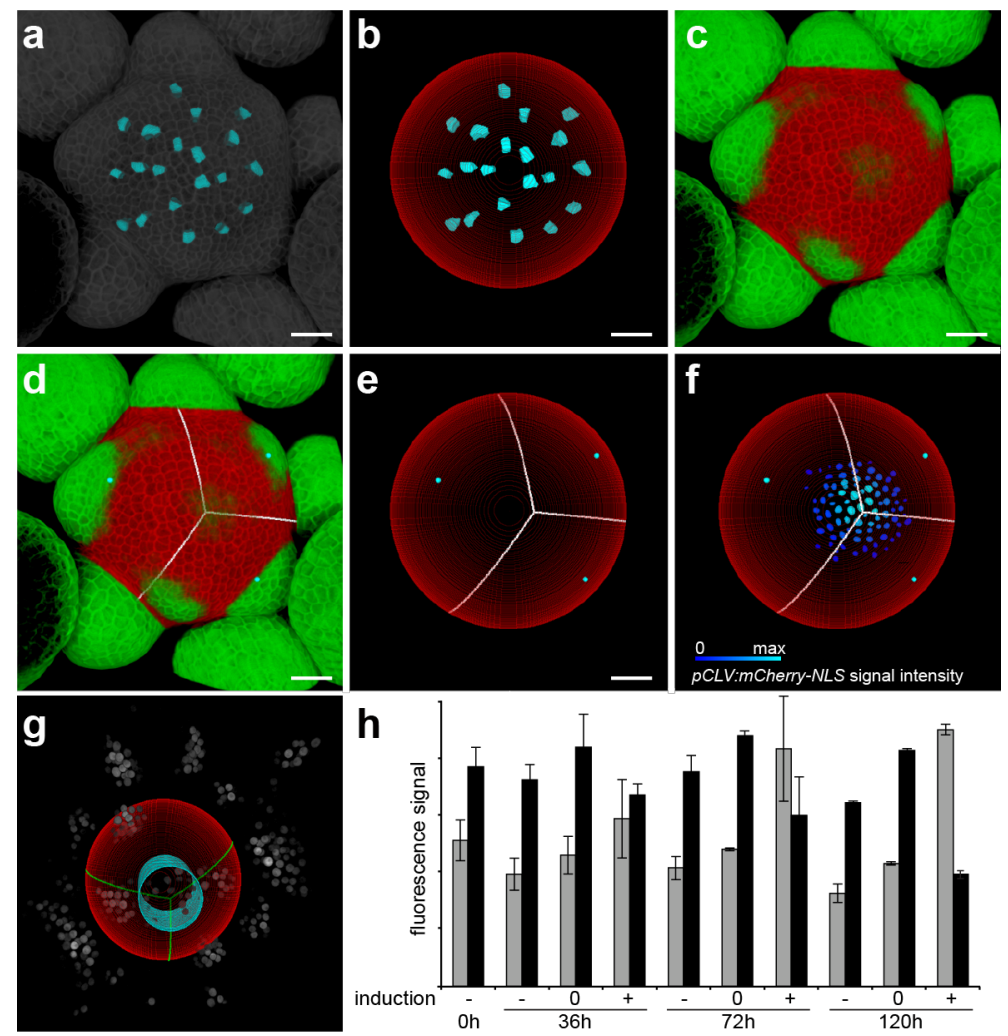

Supplementary Figure 1: Computational strategy to identify stem cells and DR5v2 quantification.

a) In a first step, cells across the L1 of the SAM are segmented. b) Based on the position of segmented cells, a perfect sphere is fitted to the SAM. c) The sphere is applied to the SAM and organ primordia are identified by emergence through the sphere. d, e) Equidistant points between the primordia are calculated and used to triangulate the center of the SAM. f) The triangulated center was benchmarked against SAMs haboring $p C L V 3$ reporter labelled stem cells $(n=9)$. The triangulation invariantly identified one of the most central $p C L V 3$ positive cells. See also Methods. g) For signal quantification in the stem cell domain, a cylinder with radius $r_{\text {cyl }}\left(=1 / 3{ }^{*} r_{\text {sphere }}\right)$ mimicking the average size of the CLV3 domain was placed into the computationally identified center of the SAM and fluorescence intensities were quantified within this narrowly defined subdomain. DR5v2-NLS signals are shown in grey, SAM sphere derived from segmentation in red, triangulation lines in green and quantification cylinder in cyan. $\mathbf{h}$ ) Quantification of fluorescent signals from all SAMs of the stem cell loss experiment described in Fig. 2. Total fluorescence signal intensities for pDR5V2:3xVENUS-NLS and pRPS5a:NLS-tdTomato for the inner region (I cyll $\left._{1}\right)$ and for the peripheral region $\left(I_{\text {sphere }}\right)$ were extracted from respective image volumes. $I_{\text {cyl }}$ was 
averaged over all plants for each time-point and condition and normalized to the overall signal $\left(I_{\text {cyl }}+I_{\text {sphere }}\right)$. Grey bars: DR5v2:3xVENUS-NLS signal, black bars: pRPS5a:NLS-tdTomato signal. - : mock treated, 0: ethanol induced, but no observable stem cell loss, + : ethanol induced and stem cell loss. Scale bars: $20 \mu \mathrm{m}$. 

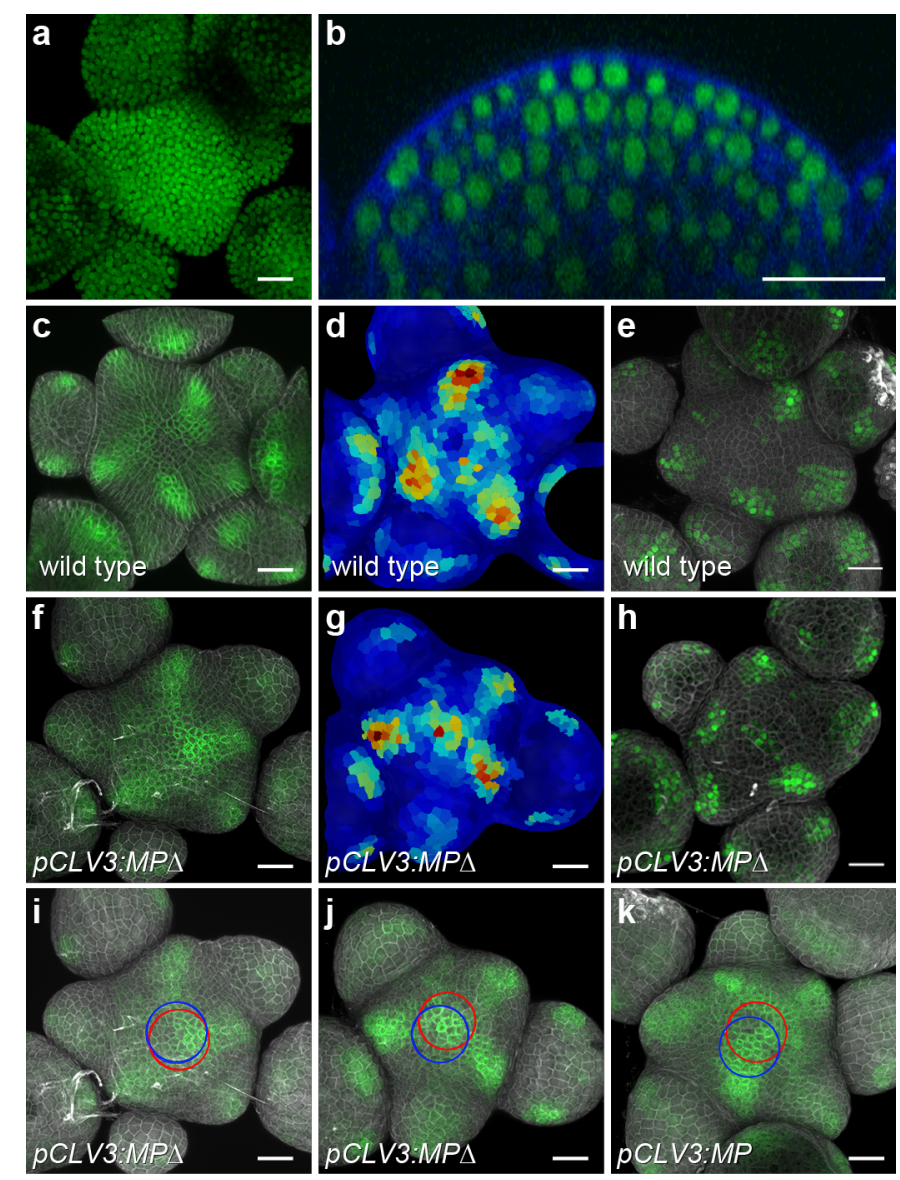

\section{Supplementary Figure 2: Activity of the pHMG promoter, behavior of nuclear and} ER localized DR5v2 reporters and auxin signaling output in wild type and pCLV3:MPA lines.

a, b) Transgenic line carrying 1347 bp upstream of the At1g76110 locus fused to the GFP-NLS coding sequence. a) GFP channel in top view. b) Side view though a representative SAM showing DAPI and GFP channel. c) pDR5v2:ER-EYFP-HDEL in wild type. d) Per cell quantification of an independent $p D R 5 v 2: E R-E Y F P-H D E L$ wildtype SAM. e) pDR5V2:3xVENUS-NLS in wild type. f-k) Auxin signaling output was present in the centre of $p C L V 3: M P$ and $p C L V 3: M P \triangle$ lines, indicated by two independent reporters $p D R 5 \mathrm{~V} 2$ :ER-EYFP-HDEL (6 out of 8 independent T1 plants) (F) and pDR5V2:3xVENUS-NLS (6 out of 7 independent T1 plants) $(\mathrm{H})$. g) Per cell quantification of $p D R 5 v 2: E R-E Y F P-H D E L$ in an independent $p C L V 3: M P \triangle$ SAM. DR5v2 activity was not observed in the center of wild-type SAMs grown in the same experiments. i-k) Computationally derived central zone in L1 (red) and L3 (blue) are superimposed to SAMs of $p D R 5 v 2$ :ER-EYFP-HDEL carrying $p C L V 3: M P \Delta(\mathrm{I}, \mathrm{J})$ and pCLV3:MP (K). DR5v2 signal clearly coincides with central zone. Scale bars: $20 \mu \mathrm{m}$. 

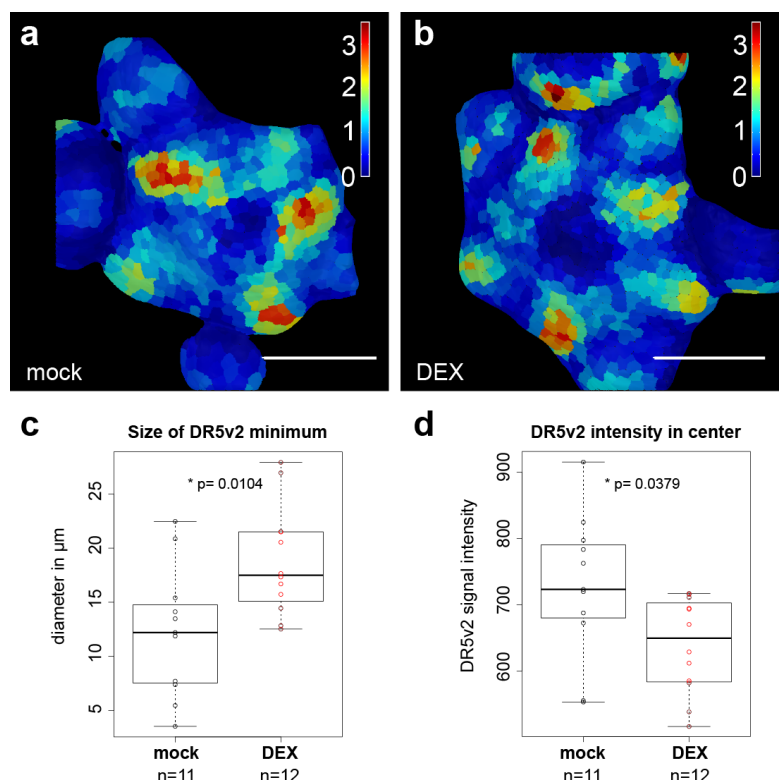

d
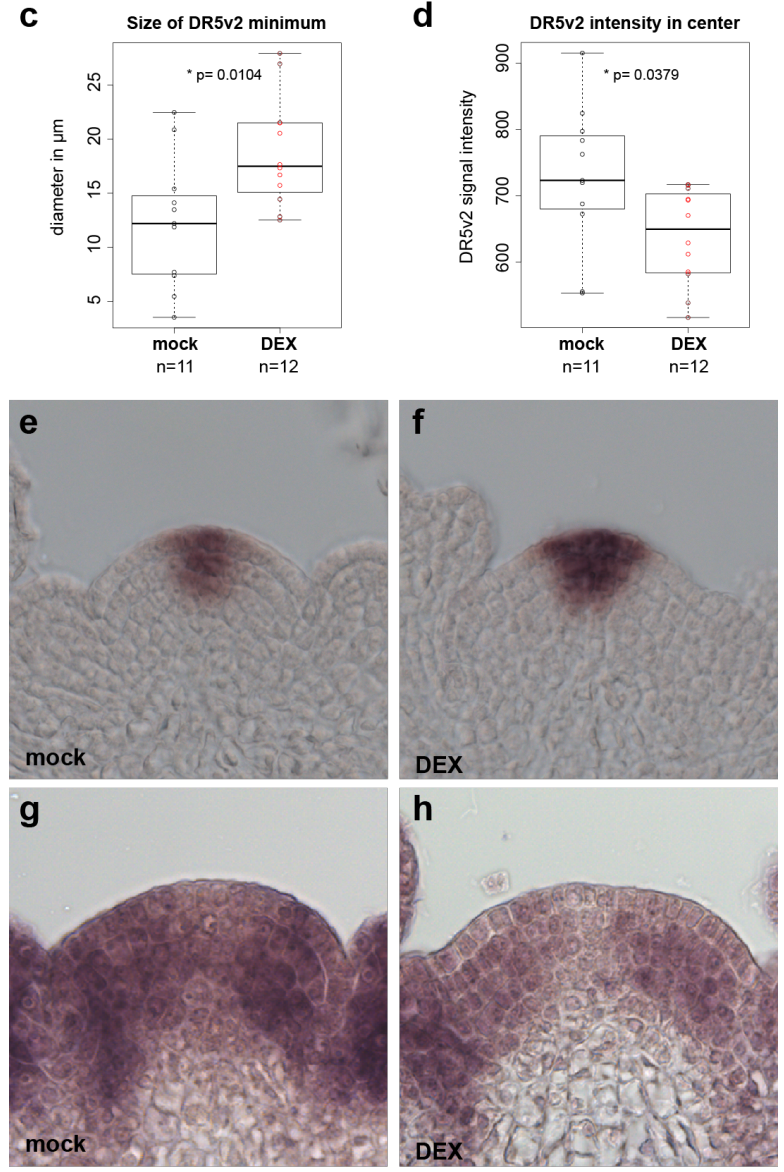

\section{Supplementary Figure 3: SAM specific molecular responses to ectopic WUS induction.}

24 hours after induction of ectopic WUS-GR activity, DR5v2 signal in the central zone was supressed and CLV3 mRNA expression was enhanced. Representative in situ quantifications of DR5v2 signal after mock (a) and DEX (b) treatments. c) Quantification of the size of the central DR5v2 minimum. d) Quantification of the average DR5v2 signal intensity in the central zone. e) CLV3 mRNA expression after 24 hours of mock treatment. f) CLV3 mRNA expression after 24 hours of DEX treatment. g) TIR1 mRNA expression after 24 hours of mock treatment. h) TIR1 mRNA expression after 24 hours of DEX treatment. SAMs of both treatment types were hybridized on the same microscopic slide and imaged under identical settings. 

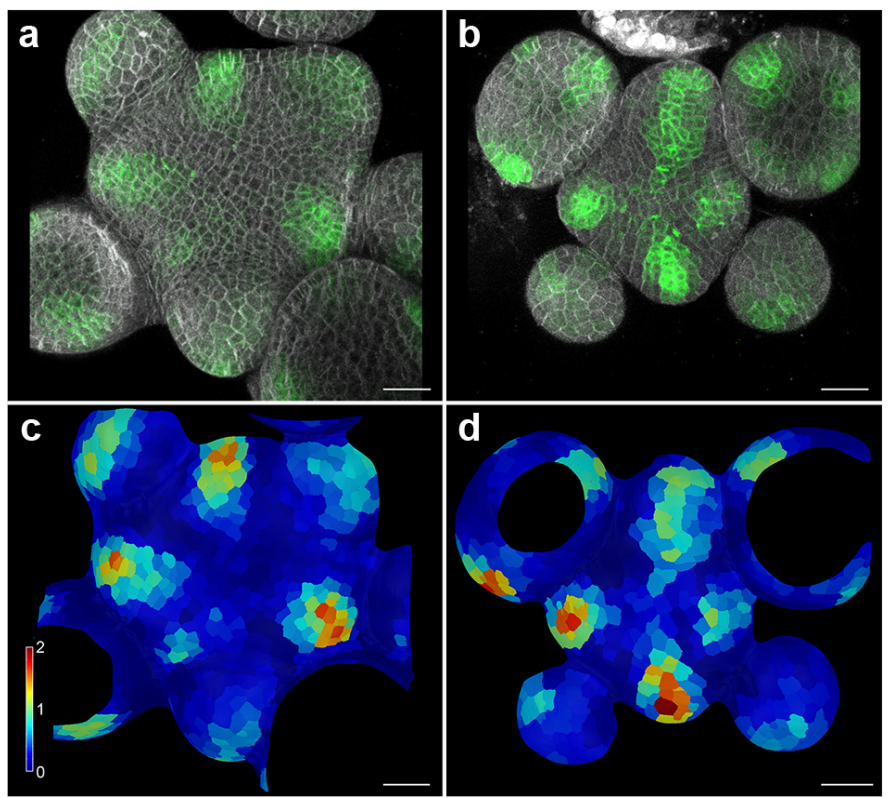

Supplementary Figure 4: SAMs of wus-7 plants show auxin signaling output in the stem cell domain.

a) Representative image of $p D R 5 v 2: E R-e Y F P-H D E L$ signal in the SAM of Ler wildtype plants. Only $16 \%$ of plants showed DR5v2 activity in the center of the SAM $(n=38)$. b) Representative image of $p D R 5 v 2: E R$-eYFP-HDEL signal in a wus-7 SAM before termination. $61 \%$ of wus-7 plants showed DR5v2 activity in the center of the SAM $(n=13)$. Per cell quantification of DR5v2 signal in wild type (c) and wus-7 (d). Scale bars: $20 \mu \mathrm{m}$ 
bioRxiv preprint doi: https://doi.org/10.1101/468421; this version posted January 10,2019 . The copyright holder for this preprint (which was not certified by peer review) is the author/funder, who has granted bioRxiv a license to display the preprint in perpetuity. It is made available under aCC-BY-NC-ND 4.0 International license.
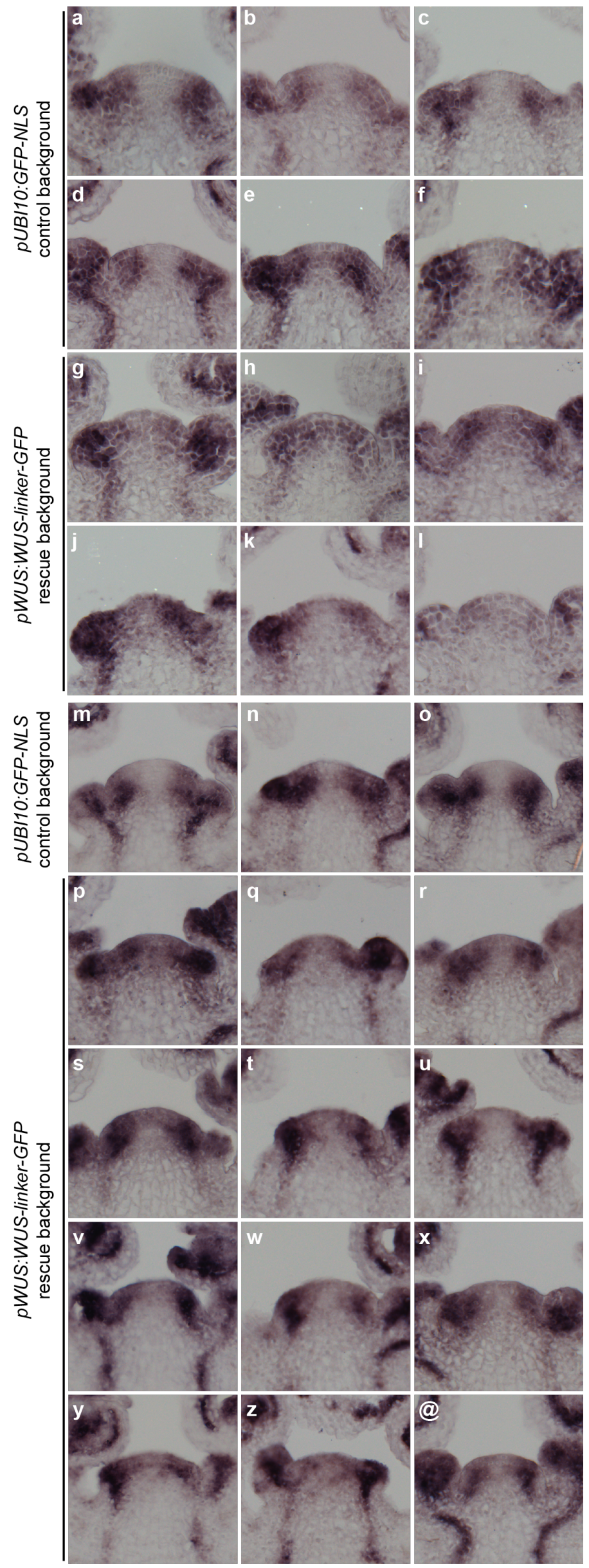


\section{Supplementary Figure 5: MP mRNA expression after induced WUS loss of function. In two independent experiments.}

a-I) Experiment I. a-f) In situ detection of MP mRNA in pUB/10:GFP-NLS control plants carrying $p C L V 3: A / C R / A I C A: N S I m b$-vhhGFP4 after 24h of ethanol treatment. g-I) In situ detection of MP mRNA in stable pWUS:WUS-linker-GFP wUs rescue plants carrying $p C L V 3: A / C R / A / C A: N S I m b-v h h G F P 4$ after $24 \mathrm{~h}$ of ethanol treatment.

m-@) Experiment II. m-o) In situ detection of MP mRNA in pUB/10:GFP-NLS control plants carrying $p C L V 3: A / C R / A / C A: N S I m b$-vhhGFP4 after $24 \mathrm{~h}$ of ethanol treatment. $\mathbf{p}$ @) In situ detection of MP mRNA in stable pWUS:WUS-linker-GFP wus rescue plants carrying $p C L V 3: A / C R / A / C A: N S I m b$-vhhGFP4 after $24 \mathrm{~h}$ of ethanol treatment.

SAMs of both genotypes were hybridized in sets of two independent experiments and imaged under identical settings. Unadjusted images are shown. 


\section{Supplementary Tables 1-2}

\begin{tabular}{|c|c|c|c|c|c|c|}
\hline & GO ID & Term & Annotated & Significant & Expected & p-Value \\
\hline 1 & GO:0010200 & response to chitin & 393 & 145 & 55.45 & $2.8 \mathrm{E}-30$ \\
\hline 2 & GO:0009611 & response to wounding & 313 & 109 & 44.16 & $1 \mathrm{E}-20$ \\
\hline 3 & GO:0010363 & $\begin{array}{l}\text { regulation of plant-type } \\
\text { hypersensitive response }\end{array}$ & 336 & 111 & 47.41 & $4.6 \mathrm{E}-19$ \\
\hline 4 & GO:0006612 & $\begin{array}{l}\text { protein targeting to } \\
\text { membrane }\end{array}$ & 340 & 111 & 47.97 & $1.3 \mathrm{E}-18$ \\
\hline 5 & GO:0009414 & $\begin{array}{l}\text { response to water } \\
\text { deprivation }\end{array}$ & 374 & 130 & 52.77 & $5.7 \mathrm{E}-18$ \\
\hline 6 & GO:0009867 & $\begin{array}{l}\text { jasmonic acid mediated } \\
\text { signaling pathway }\end{array}$ & 256 & 89 & 36.12 & $1.2 \mathrm{E}-15$ \\
\hline 7 & GO:0009733 & response to auxin & 354 & 107 & 49.95 & $2.3 \mathrm{E}-15$ \\
\hline 8 & GO:0002679 & $\begin{array}{l}\text { respiratory burst involved in } \\
\text { defense response }\end{array}$ & 114 & 50 & 16.09 & $1.1 \mathrm{E}-14$ \\
\hline 9 & GO:0009737 & response to abscisic acid & 548 & 174 & 77.32 & $1.1 \mathrm{E}-14$ \\
\hline 10 & GO:0009738 & $\begin{array}{l}\text { abscisic acid-activated } \\
\text { signaling pathway }\end{array}$ & 232 & 78 & 32.74 & $1.1 \mathrm{E}-12$ \\
\hline 11 & GO:0009651 & response to salt stress & 704 & 187 & 99.33 & $2.6 \mathrm{E}-12$ \\
\hline 12 & GO:0009695 & $\begin{array}{l}\text { jasmonic acid biosynthetic } \\
\text { process }\end{array}$ & 125 & 49 & 17.64 & $3.4 \mathrm{E}-12$ \\
\hline 13 & GO:0006857 & oligopeptide transport & 97 & 41 & 13.69 & $1.1 \mathrm{E}-11$ \\
\hline 14 & GO:0050832 & $\begin{array}{l}\text { defense response to } \\
\text { fungus }\end{array}$ & 303 & 84 & 42.75 & $3.3 \mathrm{E}-10$ \\
\hline 15 & GO:0009862 & $\begin{array}{l}\text { systemic acquired } \\
\text { resistance, salicylic acid } \\
\text { mediated signaling } \\
\text { pathway }\end{array}$ & 222 & 66 & 31.32 & $1.2 \mathrm{E}-9$ \\
\hline 16 & GO:0042538 & $\begin{array}{l}\text { hyperosmotic salinity } \\
\text { response }\end{array}$ & 152 & 50 & 21.45 & $2.9 \mathrm{E}-9$ \\
\hline 17 & GO:0009612 & $\begin{array}{l}\text { response to mechanical } \\
\text { stimulus }\end{array}$ & 59 & 27 & 8.32 & $4.5 \mathrm{E}-9$ \\
\hline 18 & GO:0042742 & $\begin{array}{l}\text { defense response to } \\
\text { bacterium }\end{array}$ & 344 & 93 & 48.54 & $4.9 \mathrm{E}-9$ \\
\hline 19 & GO:0009684 & $\begin{array}{l}\text { indoleacetic acid } \\
\text { biosynthetic process }\end{array}$ & 94 & 36 & 13.26 & $5.2 \mathrm{E}-9$ \\
\hline 20 & GO:0006569 & $\begin{array}{l}\text { tryptophan catabolic } \\
\text { process }\end{array}$ & 67 & 29 & 9.45 & $6 \mathrm{E}-9$ \\
\hline 21 & GO:0009723 & response to ethylene & 325 & 101 & 45.86 & $1.2 \mathrm{E}-8$ \\
\hline 22 & GO:0009753 & response to jasmonic acid & 427 & 141 & 60.25 & $1.2 \mathrm{E}-8$ \\
\hline 23 & GO:0009873 & $\begin{array}{l}\text { ethylene-activated } \\
\text { signaling pathway }\end{array}$ & 118 & 41 & 16.65 & $1.3 \mathrm{E}-8$ \\
\hline 24 & GO:0009620 & response to fungus & 440 & 132 & 62.08 & $2.5 \mathrm{E}-8$ \\
\hline 25 & GO:0000165 & MAPK cascade & 197 & 57 & 27.8 & $4.5 \mathrm{E}-8$ \\
\hline 26 & GO:0009963 & $\begin{array}{l}\text { positive regulation of } \\
\text { flavonoid biosynthetic } \\
\text { process }\end{array}$ & 93 & 34 & 13.12 & $5.3 \mathrm{E}-8$ \\
\hline 27 & GO:0006355 & $\begin{array}{l}\text { regulation of transcription, } \\
\text { DNA-templated }\end{array}$ & 1588 & 296 & 224.07 & $7.1 \mathrm{E}-8$ \\
\hline 28 & GO:0043069 & $\begin{array}{l}\text { negative regulation of } \\
\text { programmed cell death }\end{array}$ & 158 & 48 & 22.29 & $1 \mathrm{E}-7$ \\
\hline 29 & GO:0009739 & response to gibberellin & 143 & 49 & 20.18 & $1.1 \mathrm{E}-7$ \\
\hline 30 & GO:0031348 & $\begin{array}{l}\text { negative regulation of } \\
\text { defense response }\end{array}$ & 246 & 65 & 34.71 & $2.3 \mathrm{E}-7$ \\
\hline 31 & GO:0009409 & response to cold & 539 & 118 & 76.05 & $4.2 \mathrm{E}-7$ \\
\hline 32 & GO:0009750 & response to fructose & 127 & 39 & 17.92 & 0.0000011 \\
\hline 33 & GO:0030968 & $\begin{array}{l}\text { endoplasmic reticulum } \\
\text { unfolded protein response }\end{array}$ & 171 & 48 & 24.13 & 0.0000013 \\
\hline 34 & GO:0009693 & $\begin{array}{l}\text { ethylene biosynthetic } \\
\text { process }\end{array}$ & 110 & 35 & 15.52 & 0.0000016 \\
\hline 35 & GO:0009805 & $\begin{array}{l}\text { coumarin biosynthetic } \\
\text { process }\end{array}$ & 51 & 21 & 7.2 & 0.000002 \\
\hline 36 & GO:0010310 & $\begin{array}{l}\text { regulation of hydrogen } \\
\text { peroxide metabolic process }\end{array}$ & 159 & 45 & 22.43 & 0.0000022 \\
\hline 37 & GO:0030003 & cellular cation homeostasis & 146 & 42 & 20.6 & 0.000003 \\
\hline 38 & GO:0007623 & circadian rhythm & 156 & 44 & 22.01 & 0.0000032 \\
\hline 39 & GO:0006833 & water transport & 118 & 36 & 16.65 & 0.0000034 \\
\hline
\end{tabular}


bioRxiv preprint doi: https://doi.org/10.1101/468421; this version posted January 10,2019 . The copyright holder for this preprint (which was not certified by peer review) is the author/funder, who has granted bioRxiv a license to display the preprint in perpetuity. It is made available under aCC-BY-NC-ND 4.0 International license.

\begin{tabular}{|c|c|c|c|c|c|c|}
\hline 40 & GO:0009741 & $\begin{array}{l}\text { response to } \\
\text { brassinosteroid }\end{array}$ & 102 & 37 & 14.39 & 0.0000036 \\
\hline 41 & GO:0080167 & response to karrikin & 114 & 35 & 16.09 & 0.000004 \\
\hline 42 & GO:0002237 & $\begin{array}{l}\text { response to molecule of } \\
\text { bacterial origin }\end{array}$ & 97 & 31 & 13.69 & 0.0000056 \\
\hline 43 & GO:0006979 & $\begin{array}{l}\text { response to oxidative } \\
\text { stress }\end{array}$ & 407 & 90 & 57.43 & 0.0000065 \\
\hline 44 & GO:0006813 & potassium ion transport & 35 & 16 & 4.94 & 0.0000066 \\
\hline 45 & GO:0046777 & $\begin{array}{l}\text { protein } \\
\text { autophosphorylation }\end{array}$ & 131 & 37 & 18.48 & 0.000018 \\
\hline 46 & GO:0006598 & $\begin{array}{l}\text { polyamine catabolic } \\
\text { process }\end{array}$ & 34 & 15 & 4.8 & 0.000022 \\
\hline 47 & GO:0035556 & $\begin{array}{l}\text { intracellular signal } \\
\text { transduction }\end{array}$ & 446 & 133 & 62.93 & 0.000023 \\
\hline 48 & GO:0009269 & response to desiccation & 31 & 14 & 4.37 & 0.00003 \\
\hline 49 & GO:0031347 & $\begin{array}{l}\text { regulation of defense } \\
\text { response }\end{array}$ & 485 & 146 & 68.43 & 0.00003 \\
\hline 50 & GO:0009825 & $\begin{array}{l}\text { multidimensional cell } \\
\text { growth }\end{array}$ & 96 & 29 & 13.55 & 0.000037 \\
\hline 51 & GO:0009697 & $\begin{array}{l}\text { salicylic acid biosynthetic } \\
\text { process }\end{array}$ & 181 & 46 & 25.54 & 0.000037 \\
\hline 52 & GO:0019344 & $\begin{array}{l}\text { cysteine biosynthetic } \\
\text { process }\end{array}$ & 181 & 46 & 25.54 & 0.000037 \\
\hline 53 & GO:0006970 & response to osmotic stress & 749 & 207 & 105.68 & 0.000041 \\
\hline 54 & GO:0070838 & divalent metal ion transport & 184 & 53 & 25.96 & 0.000069 \\
\hline 55 & GO:0009627 & $\begin{array}{l}\text { systemic acquired } \\
\text { resistance }\end{array}$ & 395 & 109 & 55.73 & 0.000077 \\
\hline 56 & GO:0006949 & syncytium formation & 19 & 10 & 2.68 & 0.000083 \\
\hline 57 & GO:0042398 & $\begin{array}{l}\text { cellular modified amino } \\
\text { acid biosynthetic process }\end{array}$ & 50 & 18 & 7.06 & 0.000091 \\
\hline 58 & GO:0009751 & response to salicylic acid & 423 & 122 & 59.69 & 0.000098 \\
\hline 59 & GO:0042631 & $\begin{array}{l}\text { cellular response to water } \\
\text { deprivation }\end{array}$ & 59 & 20 & 8.32 & 0.0001 \\
\hline 60 & GO:0009965 & leaf morphogenesis & 186 & 49 & 26.24 & 0.00011 \\
\hline 61 & GO:0010583 & $\begin{array}{l}\text { response to } \\
\text { cyclopentenone }\end{array}$ & 132 & 35 & 18.63 & 0.00012 \\
\hline 62 & GO:0001666 & response to hypoxia & 74 & 23 & 10.44 & 0.00014 \\
\hline 63 & GO:0007030 & Golgi organization & 160 & 40 & 22.58 & 0.00017 \\
\hline 64 & GO:0016126 & sterol biosynthetic process & 150 & 38 & 21.17 & 0.00018 \\
\hline 65 & GO:0019748 & $\begin{array}{l}\text { secondary metabolic } \\
\text { process }\end{array}$ & 527 & 133 & 74.36 & 0.00022 \\
\hline 66 & GO:0006468 & protein phosphorylation & 620 & 157 & 87.48 & 0.00024 \\
\hline 67 & GO:0006995 & $\begin{array}{l}\text { cellular response to } \\
\text { nitrogen starvation }\end{array}$ & 21 & 10 & 2.96 & 0.00024 \\
\hline 68 & GO:0009863 & $\begin{array}{l}\text { salicylic acid mediated } \\
\text { signaling pathway }\end{array}$ & 315 & 92 & 44.45 & 0.00028 \\
\hline 69 & GO:0009407 & toxin catabolic process & 180 & 43 & 25.4 & 0.00029 \\
\hline 70 & GO:0009595 & detection of biotic stimulus & 92 & 26 & 12.98 & 0.0003 \\
\hline 71 & GO:0046686 & response to cadmium ion & 415 & 84 & 58.56 & 0.00033 \\
\hline 72 & GO:0006816 & calcium ion transport & 108 & 29 & 15.24 & 0.00036 \\
\hline 73 & GO:0042335 & cuticle development & 42 & 15 & 5.93 & 0.00038 \\
\hline 74 & GO:0009617 & response to bacterium & 499 & 140 & 70.41 & 0.0004 \\
\hline 75 & GO:0010264 & $\begin{array}{l}\text { myo-inositol } \\
\text { hexakisphosphate } \\
\text { biosynthetic process }\end{array}$ & 51 & 17 & 7.2 & 0.00041 \\
\hline 76 & GO:0010119 & $\begin{array}{l}\text { regulation of stomatal } \\
\text { movement }\end{array}$ & 47 & 16 & 6.63 & 0.00046 \\
\hline 77 & GO:0043900 & $\begin{array}{l}\text { regulation of multi- } \\
\text { organism process }\end{array}$ & 115 & 30 & 16.23 & 0.00049 \\
\hline 78 & GO:0010017 & $\begin{array}{l}\text { red or far-red light signaling } \\
\text { pathway }\end{array}$ & 39 & 14 & 5.5 & 0.00056 \\
\hline 79 & GO:0010260 & animal organ senescence & 27 & 11 & 3.81 & 0.00063 \\
\hline 80 & GO:0009740 & $\begin{array}{l}\text { gibberellic acid mediated } \\
\text { signaling pathway }\end{array}$ & 72 & 21 & 10.16 & 0.0007 \\
\hline 81 & GO:0007169 & $\begin{array}{l}\text { transmembrane receptor } \\
\text { protein tyrosine kinase } \\
\text { signaling pathway }\end{array}$ & 113 & 29 & 15.94 & 0.0008 \\
\hline 82 & GO:0015824 & proline transport & 68 & 20 & 9.59 & 0.00083 \\
\hline 83 & GO:0010227 & floral organ abscission & 32 & 12 & 4.52 & 0.00088 \\
\hline
\end{tabular}


bioRxiv preprint doi: https://doi.org/10.1101/468421; this version posted January 10, 2019. The copyright holder for this preprint (which was not certified by peer review) is the author/funder, who has granted bioRxiv a license to display the preprint in perpetuity. It is made available under aCC-BY-NC-ND 4.0 International license.

\begin{tabular}{|c|c|c|c|c|c|c|}
\hline 84 & GO:0052541 & $\begin{array}{l}\text { plant-type cell wall } \\
\text { cellulose metabolic process }\end{array}$ & 24 & 10 & 3.39 & 0.0009 \\
\hline 85 & GO:0010158 & $\begin{array}{l}\text { abaxial cell fate } \\
\text { specification }\end{array}$ & 7 & 5 & 0.99 & 0.00091 \\
\hline 86 & GO:0009742 & $\begin{array}{l}\text { brassinosteroid mediated } \\
\text { signaling pathway }\end{array}$ & 37 & 13 & 5.22 & 0.0011 \\
\hline 87 & GO:0048767 & root hair elongation & 164 & 38 & 23.14 & 0.00117 \\
\hline 88 & GO:0010118 & stomatal movement & 86 & 32 & 12.13 & 0.00168 \\
\hline 89 & GO:0009694 & $\begin{array}{l}\text { jasmonic acid metabolic } \\
\text { process }\end{array}$ & 147 & 58 & 20.74 & 0.00171 \\
\hline 90 & GO:0033500 & carbohydrate homeostasis & 12 & 8 & 1.69 & 0.00174 \\
\hline 91 & GO:0007231 & $\begin{array}{l}\text { osmosensory signaling } \\
\text { pathway }\end{array}$ & 5 & 4 & 0.71 & 0.00175 \\
\hline 92 & GO:2000022 & $\begin{array}{l}\text { regulation of jasmonic acid } \\
\text { mediated signaling } \\
\text { pathway }\end{array}$ & 5 & 4 & 0.71 & 0.00175 \\
\hline 93 & GO:0010037 & response to carbon dioxide & 5 & 4 & 0.71 & 0.00175 \\
\hline 94 & GO:0009624 & response to nematode & 72 & 20 & 10.16 & 0.0018 \\
\hline 95 & GO:0006766 & vitamin metabolic process & 77 & 21 & 10.86 & 0.0018 \\
\hline 96 & GO:0006865 & amino acid transport & 228 & 61 & 32.17 & 0.00209 \\
\hline 97 & GO:0000038 & $\begin{array}{l}\text { very long-chain fatty acid } \\
\text { metabolic process }\end{array}$ & 44 & 14 & 6.21 & 0.00214 \\
\hline 98 & GO:0046885 & $\begin{array}{l}\text { regulation of hormone } \\
\text { biosynthetic process }\end{array}$ & 8 & 5 & 1.13 & 0.00215 \\
\hline 99 & GO:0050801 & ion homeostasis & 205 & 59 & 28.93 & 0.00226 \\
\hline 100 & GO:0052546 & $\begin{array}{l}\text { cell wall pectin metabolic } \\
\text { process }\end{array}$ & 40 & 13 & 5.64 & 0.00247 \\
\hline
\end{tabular}

Supplementary Table 1: GO category enrichment analysis of direct WUS targets.

Top 100 enriched categories are shown. 
bioRxiv preprint doi: $h$ ttps://doi.org/10.1101/468421; this version posted January 10,2019 . The copyright holder for this preprint (which was not certified by peer review) is the author/funder, who has granted bioRxiv a license to display the preprint in perpetuity. It is made available under aCC-BY-NC-ND 4.0 International license.

\begin{tabular}{|c|c|c|c|c|}
\hline AGI & Gene Name & \# WUS peaks & Log2FC & p adj. \\
\hline AT1G59750 & ARF1 & 0 & $-0,092540577$ & 0,425729231 \\
\hline AT5G62000 & ARF2 & 1 & $-0,141313595$ & 0,070074796 \\
\hline AT2G33860 & ARF3 & 1 & 0,775921196 & $2,11 \mathrm{E}-06$ \\
\hline AT5G60450 & ARF4 & 1 & $-1,258170789$ & $4,76 \mathrm{E}-18$ \\
\hline AT1G19850 & ARF5 & 1 & 0,864357040 & 0,000125261 \\
\hline AT1G30330 & ARF6 & 5 & 0,294727963 & 0,014033872 \\
\hline AT5G20730 & ARF7 & 0 & 0,171498773 & 0,24584083 \\
\hline AT5G37020 & ARF8 & 1 & $-1,575709325$ & $8,52 \mathrm{E}-20$ \\
\hline AT4G23980 & ARF9 & 1 & 1,153767834 & $5,92 \mathrm{E}-25$ \\
\hline AT2G28350 & ARF10 & 2 & 0,847838948 & 0,000948755 \\
\hline AT2G46530 & ARF11 & 1 & 0,925587920 & 4,27E-07 \\
\hline AT1G34310* & ARF12 & 0 & 0 & 1 \\
\hline AT1G34170* & ARF13 & 0 & 0 & 1 \\
\hline AT1G35540* & ARF14 & 0 & 0 & 1 \\
\hline AT1G35520* & ARF15 & 0 & 0 & 1 \\
\hline AT4G30080 & ARF16 & 0 & 0,143765542 & 0,628545091 \\
\hline AT1G77850 & ARF17 & 0 & 0,867761468 & $4,19 \mathrm{E}-05$ \\
\hline AT3G61830* & ARF18 & 0 & 0,989685885 & $7,48 \mathrm{E}-15$ \\
\hline AT1G19220 & ARF19 & 0 & 1,115504426 & 2,96E-09 \\
\hline AT1G35240* & ARF20 & 0 & 0 & 1 \\
\hline AT1G34410* & ARF21 & 0 & 0 & 1 \\
\hline AT1G34390* & ARF22 & 0 & 0 & 1 \\
\hline AT1G43950* & ARF23 & 0 & 0 & 1 \\
\hline AT4G14560 & IAA1 & 1 & $-0,026815594$ & 0,947757473 \\
\hline AT3G23030 & IAA2 & 2 & $-0,763296850$ & $2,39 \mathrm{E}-21$ \\
\hline AT1G04240 & SHY2 & 2 & 3,215535318 & $4,66 \mathrm{E}-121$ \\
\hline AT5G43700 & ATAUX2-11 & 1 & $-0,449766274$ & $2,15 \mathrm{E}-05$ \\
\hline AT1G15580* & IAA5 & 0 & 0 & 1 \\
\hline AT1G52830 & IAA6 & 2 & 0 & 1 \\
\hline AT3G23050 & IAA7 & 1 & 0,572994647 & $4,02 \mathrm{E}-07$ \\
\hline AT2G22670 & IAA8 & 2 & 1,394465988 & $6,40 \mathrm{E}-43$ \\
\hline AT5G65670 & IAA9 & 2 & 0,124793826 & $1,41 \mathrm{E}-01$ \\
\hline AT1G04100* & IAA10 & 0 & $-1,709850381$ & $2,57 \mathrm{E}-14$ \\
\hline AT4G28640 & IAA11 & 0 & $-0,679861940$ & $1,26 \mathrm{E}-02$ \\
\hline AT1G04550 & IAA12 & 1 & $-0,559301573$ & 0,012657873 \\
\hline AT2G33310 & IAA13 & 1 & $-0,996497622$ & $2,41 \mathrm{E}-15$ \\
\hline AT4G14550 & IAA14 & 2 & $-0,578151620$ & 0,006372765 \\
\hline AT1G80390 & IAA15 & 0 & 0 & 1 \\
\hline AT3G04730 & IAA16 & 1 & $-0,387494366$ & $2,49 \mathrm{E}-09$ \\
\hline AT1G04250 & AXR3 & 1 & 0,668789409 & $1,70 \mathrm{E}-04$ \\
\hline AT1G51950 & IAA18 & 3 & $-0,752605675$ & $2,02 \mathrm{E}-11$ \\
\hline AT3G15540 & IAA19 & 2 & 1,441217799 & $1,10 \mathrm{E}-03$ \\
\hline AT2G46990 & IAA20 & 1 & 1,931969488 & $4,30 \mathrm{E}-16$ \\
\hline AT3G16500 & PAP1 & 2 & $-1,484257914$ & $1,32 \mathrm{E}-35$ \\
\hline AT4G29080 & PAP2 & 1 & 0,879788470 & $7,44 \mathrm{E}-07$ \\
\hline AT5G25890 & IAA28 & 0 & $-0,277043301$ & 0,253529454 \\
\hline AT4G32280 & IAA29 & 0 & 1,973159875 & $3,36 \mathrm{E}-07$ \\
\hline AT3G62100 & IAA30 & 0 & 1,183375731 & 9,73E-04 \\
\hline AT3G17600* & IAA31 & 0 & 0 & 1 \\
\hline AT2G01200* & IAA32 & 0 & 2,883104933 & 0,081310628 \\
\hline AT1G15050* & IAA34 & 0 & $-0,443724915$ & 0,434574757 \\
\hline AT4G03190 & AFB1 & 0 & $-1,546414697$ & $3,32 \mathrm{E}-12$ \\
\hline AT3G26810 & AFB2 & 2 & $-0,145179846$ & $3,61 \mathrm{E}-01$ \\
\hline AT1G12820 & AFB3 & 0 & 1,196545030 & $1,29 \mathrm{E}-40$ \\
\hline AT4G24390 & AFB4 & 0 & 0,581458460 & 0,001034196 \\
\hline AT5G49980 & AFB5 & 1 & 0,477719550 & $4,95 \mathrm{E}-05$ \\
\hline АT3G62980 & TIR1 & 1 & $-0,871245173$ & $4,91 \mathrm{E}-18$ \\
\hline AT1G73590 & PIN1 & 1 & 0,133975925 & 0,771092197 \\
\hline AT5G57090 & PIN2 & 0 & 0,678755084 & 0,07343843 \\
\hline AT1G70940 & PIN3 & 2 & $-1,171670670$ & $1,85 \mathrm{E}-27$ \\
\hline AT2G01420 & PIN4 & 3 & 0,364037027 & 2,92E-05 \\
\hline AT5G16530* & PIN5 & 0 & $-0,976327009$ & 0,792123994 \\
\hline AT1G77110 & PIN6 & 1 & 1,567558864 & 0,056844235 \\
\hline AT1G23080 & PIN7 & 2 & $-0,170157356$ & 0,304697713 \\
\hline AT5G15100 & PIN8 & 0 & 0 & 1 \\
\hline AT2G38120 & AUX1 & 2 & 0,905501335 & $3,36 \mathrm{E}-10$ \\
\hline AT5G01240 & LAX1 & 2 & 0,159143298 & 0,207550001 \\
\hline AT2G21050 & LAX2 & 0 & 0,461205197 & 0,145235679 \\
\hline AT1G77690 & LAX3 & 1 & 0,011696012 & 0,965073056 \\
\hline AT2G34650 & PID & 2 & 0,345593382 & 0,104333098 \\
\hline AT2G26700 & PID2 & 0 & $-0,114850869$ & 0,830691073 \\
\hline
\end{tabular}

\section{Supplementary Table 2: Response of genes with activities in auxin signalling to} WUS.

Adjusted p-value for RNA-seq data was calculated using the Benjamini-Hochberg method in Deseq2. Asterisks denote genes in regions with closed chromatin ${ }^{26}$. 


\section{Materials and Methods}

\section{Plant material and treatments}

All plants were grown at $23^{\circ} \mathrm{C}$ in long days or continuous light. Ethanol inductions were performed by watering with $1 \%$ ethanol and continuous exposure to ethanol vapour, refreshed every 12 hours. WUS-GR was induced by submerging seedlings in $25 \mu \mathrm{M}$ dexamethasone, $0.015 \%$ Silwet L-70 in $0.5 x$ MS for 2 hours. For local induction at the SAM, $10 \mu \mathrm{l}$ induction solution were directly applied to the primary inflorescence meristem. Auxin plates were 0.5x MS, 1\% agar, pH 5.7, $10 \mu \mathrm{m}$ IAA. For TSA/IAA cotreatments, shoot apical meristems were dissected from about $4 \mathrm{~cm}$ high stem and cultured in vitro in Apex Growth Medium (AGM) overnight ${ }^{42}$. AGM was supplemented with vitamins (Duchefa M0409), cytokinin (200 nM 6-Benzylaminopurine), and IAA (3indole acetic acid, $1 \mathrm{mM}$ ) and/or Trichostatin A (TSA, Sigma, T8552, final concentration $5 \mu \mathrm{M})$ or mock before pouring. IAA stock solution $(0.1 \mathrm{M}$ in $0.2 \mathrm{M} \mathrm{KOH})$ was diluted with $2 \mathrm{mM}$ M.E.S ( $\mathrm{pH} 5.8$ ) to $1 \mathrm{mM}$ working solution, then added to the plates for $30 \mathrm{~min}$ before imaging on the second day.

For WUS-induction with TSA treatments, seedlings were submerged in DEX (10 $\mu \mathrm{M})$ or TSA $(1 \mu \mathrm{M})$ solution or both, slowly shaken for $2 \mathrm{~h}$, and then harvested for RNAseq.

All plants were of Col-0 accession apart from wus-7, which was in Ler background. For experiments involving wus-7, Ler plants were used as controls.

\section{Transgenes}

The R2D2 and pDR5V2:3xVENUS-NLS lines have been described in ref. 16 . pDR5v2:tdTomato-Linker-NLS:trbcS was transformed into heterozygous wus-7 plants and Lercontrol plants and activity patterns were scored in T1. A stable single insertion T3 line of pDR5v2:ER-EYFP-HDEL:tAt4g24550 was used for transformation with pCLV3:3xmCherry-NLS and signals were scored in T1. For deGradFP the anti-GFP nanobody coding sequence (NS/mb-vhhGFP4)22 was brought under control of the AlcR/AlcA system ${ }^{43}$ and transformed into a stable pWUS:WUS-linker-GFP wus rescue line (GD44, described in ref. 5), or an pUB/10:GFP-NLS line as control. Experiments were performed in stable single insertion T3 lines. Similarly, the pCLV3:AlcR/AICA:CalS3m line ${ }^{5}$ was crossed to pDR5V2:3xVENUS-NLS, pRPS5a:NLS-tdTomato and F3 single insertion progeny was used for experiments. For ectopic WUS induction lines mCherry was fused N-terminally to the ligand-binding 
domain of the rat glucocorticoid receptor (GR) and linked by (AAASAIAS[SG]11SAAA) to the WUS coding sequence under control of the pUB/10 promoter. A single insertion homozygous line was used for crossings, in RNA-seq, and ChIP-seq.

The $p H M G$ promoter corresponds to 1347 bp upstream of the AT1g76110 locus. Most constructs were assembled using GreenGate cloning ${ }^{44}$.

\section{Microscopy}

Confocal microscopy was carried out on a Nikon A1 Confocal with a CFI Apo LWD $25 \times$ water immersion objective (Nikon Instruments) as described in ref. $5.1 \mathrm{mg} / \mathrm{ml}$ DAPI was used for cell wall staining.

\section{Image analysis}

Quantitative image analysis was done on isotropic image stacks using Fiji (v1.50b) ${ }^{45}$, MorphoGraphX ${ }^{46}$, ilastik ${ }^{47}$, Matlab (Release 2014b, The MathWorks, Inc., United States) and $\mathrm{KNIME}^{48}$. Signal quantification methods: all images for an experimental set were captured under identical microscope settings and signal intensities were never adjusted, making intra-experiment signal comparisons possible. MorphographX analysis was performed according to standards defined in the user manual. Averaging and statistical analysis of signals across meristems was performed as follows: histograms of signal intensities along 100 central cross-sections per SAM were (crosssections rotated by 3.6 degrees successively) were measured by ImageJ standard function. Signals were centered for comparison between individuals. Signals +/$12.5 \mu \mathrm{m}$ around the SAM center were compared between treatment and control and tested for significance by Student's T-test. Distance from center with signal up to $120 \%$ of center background signal between treatment and control was determined and tested by Student's T-test.

To determine the center of an inflorescence meristem, 10 to $20 \mathrm{~L} 1$ cells located at the meristem summit were segmented using the carving workflow in ilastik. A sphere was fitted through the centroids of these cells using the least squared distances method. The sphere was superimposed on the original DAPI stained image volume to help identifying the newly emerging flower primordia. Three points marking the center of three young flower primordia were manually picked close to the sphere surface, projected onto the sphere and then used as seeds to perform a spheric voronoi tessellation (https://de.mathworks.com/matlabcentral/fileexchange/40989-voronoisphere). The point $\mathrm{P}_{\text {center }}$ is equidistant to the three seed points and serves as a good 
approximation for the meristem center which is marked by the pCLV3 stem cell reporter. The method was tested using image stacks of nine meristems containing cell walls stained by DAPI in one channel and the stem cell marker pCLV3::mCherry-NLS in the second channel. The computationally estimated meristem center and the one determined by $p C L V 3: m C h e r r y-N L S$ expression in every case were in the range of one cell diameter. Further details and workflows are available on request.

\section{In situ hybridization}

In-situ hybridizations were carried out as described in ref. 49.

\section{ChIP-seq and RNA-seq}

All experiments were carried out on 5 day old seedlings grown on $0.5 \mathrm{MS}$ plates after 2 hours of either Dex or mock treatment. ChIP assays were performed from $3 \mathrm{~g}$ of fresh weight each as described in ref. 50 using RFP-Trap single chain antibodies (Chromotek). Enrichment of specific DNA fragments was validated by qPCR at the $A R R 7$ promoter region ${ }^{24}$. Two independent libraries were generated for the WUS-GR and control ChIP each using pooled DNA from 6 to 9 individual ChIP preparations. RNA-seq was carried out in biological triplicates. After careful benchmarking of our WUS-GR line, we find it to be the most potent and consistent tool for WUS induction to date, affording a much higher sensitivity for identifying transcriptional targets. In addition, the use of RFP-trap increased sensitivity of the ChIP assay. Consistently, we were able to identify 6740 genomic regions bound by WUS in both ChIP-seq experiments at $p<0.05$. This compared to 136 regions we had previously identified by ChIP-chip ${ }^{23}$, highlighting the increase in power. Previously identified direct targets, such as ARR7, CLV1, KAN1, KAN2 AS2 and YAB323-25 were also picked up in our analysis. Because of the medium level ubiquitous expression of WUS, both RNA-seq and ChIP-seq capture the global regulatory potential of WUS. Since regulatory output of WUS is dependent on tissue context, targets identified here might not be relevant for all tissues. In addition, targets might be induced by WUS in one tissue and repressed in another, which cannot be resolved by this dataset. All genomic datasets are available under GEO accession: GSE122611

\section{Bioinformatics}


ChIP-seq data were mapped to TAIR10 genome by BWA aligner (v0.7.17) ${ }^{51}$ on a local Galaxy instance (v17.09)52. Peak calling was performed using Hiddendomains (v3.0) ${ }^{53}$. Peaks were annotated to TAIR10 genes using PAVIS 54 .

Alignment of RNA-seq reads to TAIR10 genome by HISAT2 (v2.1.0)55 and calculation of count matrices by featureCounts $(\mathrm{v} 1.6 .3)^{56}$ was done on Galaxy instance. Differentially expressed genes were identified with $\mathrm{R}$ bioconductor package Deseq2 $(1.20 .0)^{57}$. Gene ontology analysis was carried out using topGO R package (v2.32.0) with all genes annotated to open chromatin ${ }^{26}$ as background. 